\title{
Role of APP Interactions with Heterotrimeric G Proteins: Physiological Functions and Pathological Consequences
}

\author{
Philip F. Copenhaver ${ }^{\text {*t }}$ and Donat Kögel2† \\ ' Department of Cell, Developmental and Cancer Biology, Oregon Health \& Sciences University, Portland, OR, USA, \\ ${ }^{2}$ Experimental Neurosurgery, Goethe University Frankfurt, Frankfurt am Main, Germany
}

OPEN ACCESS

Edited by: Detlev Boison,

Legacy Health, USA

Reviewed by:

Kristina Endres,

University of Mainz, Germany

Angele Parent,

University of Chicago, USA

*Correspondence: Philip F. Copenhaver

copenhav@ohsu.edu

†These authors have contributed equally to this work.

Received: 26 October 2016 Accepted: 05 January 2017 Published: 31 January 2017

Citation:

Copenhaver PF and Kögel D (2017)

Role of APP Interactions with

Heterotrimeric G Proteins:

Physiological Functions

and Pathological Consequences.

Front. Mol. Neurosci. 10:3.

doi: 10.3389/fnmol.2017.00003
Following the discovery that the amyloid precursor protein (APP) is the source of $\beta$-amyloid peptides $(A \beta)$ that accumulate in Alzheimer's disease (AD), structural analyses suggested that the holoprotein resembles a transmembrane receptor. Initial studies using reconstituted membranes demonstrated that APP can directly interact with the heterotrimeric $\mathrm{G}$ protein $\mathrm{G} \alpha$ o (but not other $\mathrm{G}$ proteins) via an evolutionarily $\mathrm{G}$ protein-binding motif in its cytoplasmic domain. Subsequent investigations in cell culture showed that antibodies against the extracellular domain of APP could stimulate G $\alpha$ o activity, presumably mimicking endogenous APP ligands. In addition, chronically activating wild type APP or overexpressing mutant APP isoforms linked with familial AD could provoke Go-dependent neurotoxic responses, while biochemical assays using human brain samples suggested that the endogenous APP-Go interactions are perturbed in AD patients. More recently, several G protein-dependent pathways have been implicated in the physiological roles of APP, coupled with evidence that APP interacts both physically and functionally with $\mathrm{G} \alpha \mathrm{O}$ in a variety of contexts. Work in insect models has demonstrated that the APP ortholog APPL directly interacts with GaO in motile neurons, whereby APPL-Gao signaling regulates the response of migratory neurons to ligands encountered in the developing nervous system. Concurrent studies using cultured mammalian neurons and organotypic hippocampal slice preparations have shown that APP signaling transduces the neuroprotective effects of soluble SAPP $\alpha$ fragments via modulation of the PI3K/Akt pathway, providing a mechanism for integrating the stress and survival responses regulated by APP. Notably, this effect was also inhibited by pertussis toxin, indicating an essential role for $\mathrm{G} \alpha \mathrm{O} / \mathrm{i}$ proteins. Unexpectedly, C-terminal fragments (CTFs) derived from APP have also been found to interact with Gas, whereby CTF-Gas signaling can promote neurite outgrowth via adenylyl cyclase/PKA-dependent pathways. These reports offer the intriguing perspective that $\mathrm{G}$ protein switching might modulate APP-dependent responses in a context-dependent manner. In this review, we provide an up-to-date perspective on the model that APP plays a variety of roles as an atypical $G$ protein-coupled receptor in both the developing and adult nervous system, and we discuss the hypothesis that disruption of these normal functions might contribute to the progressive neuropathologies that typify AD.

Keywords: Alzheimer's disease, amyloid precursor protein, APPL, Drosophila, G $\alpha$ o, Manduca, migration, stress signaling 


\section{APP AS AN UNCONVENTIONAL G PROTEIN-COUPLED RECEPTOR: HISTORICAL PERSPECTIVE}

Members of the APP family share many of the structural features that distinguish type-1 transmembrane receptors, including evolutionarily conserved extracellular domains capable of binding a variety of candidate ligands, plus highly conserved intracellular domains that can mediate interactions with numerous cytoplasmic adapter and signaling proteins (Turner et al., 2003; Jacobsen and Iverfeldt, 2009; Deyts et al., 2016b). In addition, APP is also capable of both homodimeric binding (to itself) and heterodimeric interactions with two APP-like proteins (APLP1 and APLP2) and other membrane-associated proteins (Scheuermann et al., 2001; Soba et al., 2005; Wang et al., 2009; Kaden et al., 2012), consistent with the perspective that APP and its orthologs can function as neuronal receptors that modulate both physiological and pathological responses. Whereas receptors with the topology of APP are most commonly associated with the activation of intracellular kinases (Heldin et al., 2016; Trenker et al., 2016), a growing number of singlepass receptors have now been shown to function as authentic G protein-coupled receptors (GPCRs) that mediate cellular responses via heterotrimeric $G$ proteins, including Fibroblast Growth Factor and Epidermal Growth Factor Receptors (Patel, 2004; Hawkes et al., 2007). Based on the identification of a short motif in Insulin-like Growth Factor II receptor that binds the heterotrimeric G protein Gi (Okamoto et al., 1990), Nishimoto et al. (1993) identified a similar motif in APP (Figure 1A; described below), suggesting that APP might also function as $\mathrm{G}$ protein-interacting receptor. Specifically, they identified a 20 amino acid peptide ("peptide 20") within the intracellular domain (-His 657 -Lys 676 ; numbering in $\mathrm{APP}_{695}$ ) that could directly bind and activate heterotrimeric $G$ proteins containing $G \alpha o$ but not other $\mathrm{G} \alpha$ subunits (including $\mathrm{G} \alpha \mathrm{s}, \mathrm{G} \alpha \mathrm{i}_{1}, \mathrm{G} \alpha \mathrm{i}_{2}$, and

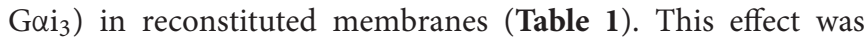
blocked by PTX (a selective inhibitor of the G $\alpha$ o/i subfamily). They also demonstrated that the alpha subunit of Go (Goo) but not Gai could be co-immunoprecipitated with APP from concentrated brain membranes, an interaction that was inhibited by adding excess peptide 20 . Using membrane preparations from

\footnotetext{
Abbreviations: $\mathrm{A} \beta$, beta-amyloid peptide derived from APP; AC, adenylyl cyclase; AD, Alzheimer's disease; AICD, APP intracellular domain cleavage fragments of APP family proteins; Akt, target of PI3K (also called Protein kinase B); APP, amyloid precursor protein; $\mathrm{APP}_{695}$, predominant isoform of APP in mammalian neurons (695 amino acids); APLP1 and APLP2, APP-Like-Proteins 1 and 2 (additional APP family members expressed in the mammalian brain); APPL, APP-Like, the insect ortholog of human APP; BiFC, bimolecular fluorescence complementation; CaMKIV, calcium/calmodulin-dependent protein kinase IV; cAMP, cyclic adenosine monophosphate; CREB, cAMP response element binding protein; CTX; cholera toxin; FAD, familial AD; Gai, alpha subunit of the heterotrimeric G protein Gi; Goo, alpha subunit of the heterotrimeric G protein Go; $G \beta \gamma$, beta/gamma dimeric subunits of heterotrimeric $G$ proteins; GSK3 $\beta$, glycogen synthase kinase 3 beta; JNK, c-Jun N-terminal kinase; pCREB, phosphorylated CREB; PI3K, phosphatidylinositol-4,5-bisphosphate 3-kinase; PKA, protein kinase A; PS-1, presenilin-1; PS-2; presenilin 2; PTX, pertussis toxin, a selective inhibitor of $\mathrm{G} \alpha \mathrm{i} / \mathrm{G} \alpha \mathrm{o}$ family of heterotrimeric G proteins; $s \mathrm{APP} \alpha$, secreted ectodomain fragments of APP generated by $\alpha$-secretase cleavage. sAPPL, secreted ectodomain fragments of insect APPL (equivalent to SAPP $\alpha$ ).
}

transfected SF9 cells, they then showed that $\mathrm{APP}_{695}$ could be co-immunoprecipitated with purified bovine Go, in contrast to mutated forms of APP lacking the peptide 20 domain (Nishimoto et al., 1993). Of note is that $\mathrm{G} \beta$ could also be detected in these immunoprecipitates, consistent with the model that APP normally interacts with Go as a heterotrimeric complex (similar to conventional GPCRs). Lastly, G $\alpha$ o was shown to specifically mediate the effects of peptide 20 on GTP hydrolysis, while pretreatment with GTP $\gamma$ S blocked this interaction (Lang et al., 1995), indicating that the activation state of Go regulates its interaction with APP (again consistent with conventional GPCRs).

In related experiments, Ikezu et al. (1996) co-expressed APP with chimeric $G \alpha$ subunits to demonstrate that the last five amino acids of $G \alpha o$ are necessary for its interactions with APP, whereas chimeras containing the cytoplasmic domains of other $\mathrm{G} \alpha$ subunits were ineffective (Table 1). This result is consistent with extensive evidence that $\mathrm{C}$-terminal residues within $\mathrm{G} \alpha$ subunits control the specificity of their interactions with conventional GPCRs (Hamm et al., 1988; Herrmann et al., 2004). In collaboration with other groups, they also showed that soluble peptide 20 could regulate Go-dependent exocytosis but had no effect on Gs-dependent membrane fusion events, further validating the model that APP specifically interacts with the C-terminal region of G $\alpha$ o (Colombo et al., 1994; Lang et al., 1995). These results provide strong evidence that the juxtamembrane G protein-binding domain in APP promotes functional interactions with $G \alpha o$ (but not other $G$ proteins), suggesting that APP might indeed function as an atypical Gocoupled receptor.

Subsequent studies explored whether stimulating APP with an antibody against its extracellular domain $(22 \mathrm{C} 11$; to mimic ligand binding) could induce $\mathrm{G} \alpha \mathrm{o}$ activity. In liposomes containing reconstituted $\mathrm{APP}_{695}$ and bovine Go, treatment with $22 \mathrm{C} 11$ induced the activation of Go (but not $\mathrm{Gi}_{2}$ ) in the absence of other proteins (Okamoto et al., 1995, 1996). Although the 22C11 antibody can also detect APLP2 (Slunt et al., 1994), other antibodies targeting different epitopes in APP (but not APLP1 or APLP2) were also found to induce Go-associated responses, including $\alpha-1680$ and Alz90 (Sudo et al., 2000). In this regard, several groups also tested whether the effects of APP on G $\alpha$ o signaling might be recapitulated by APLP1 or APLP2. Although one study showed that antibody activation of either APP or APLP2 could induce similar cytotoxic responses to 22C11 (Mbebi et al., 2002), other investigators used APP knockout lines to show that only re-expression of APP rescued Gaodependent responses, whereas expression of APLP1 and APLP2 did not (Sola Vigo et al., 2009; Milosch et al., 2014). Thus, these studies provided intriguing evidence that only APP can function as an unconventional Go-coupled receptor, albeit under rather artificial conditions.

\section{ABERRANT APP-Go SIGNALING CAN PROVOKE NEURODEGENERATION}

How might the misregulation of normal APP-Go signaling contribute to the pathology of $\mathrm{AD}$ ? To address this issue, 
A

B

\section{VMLKKKQYTSI **}

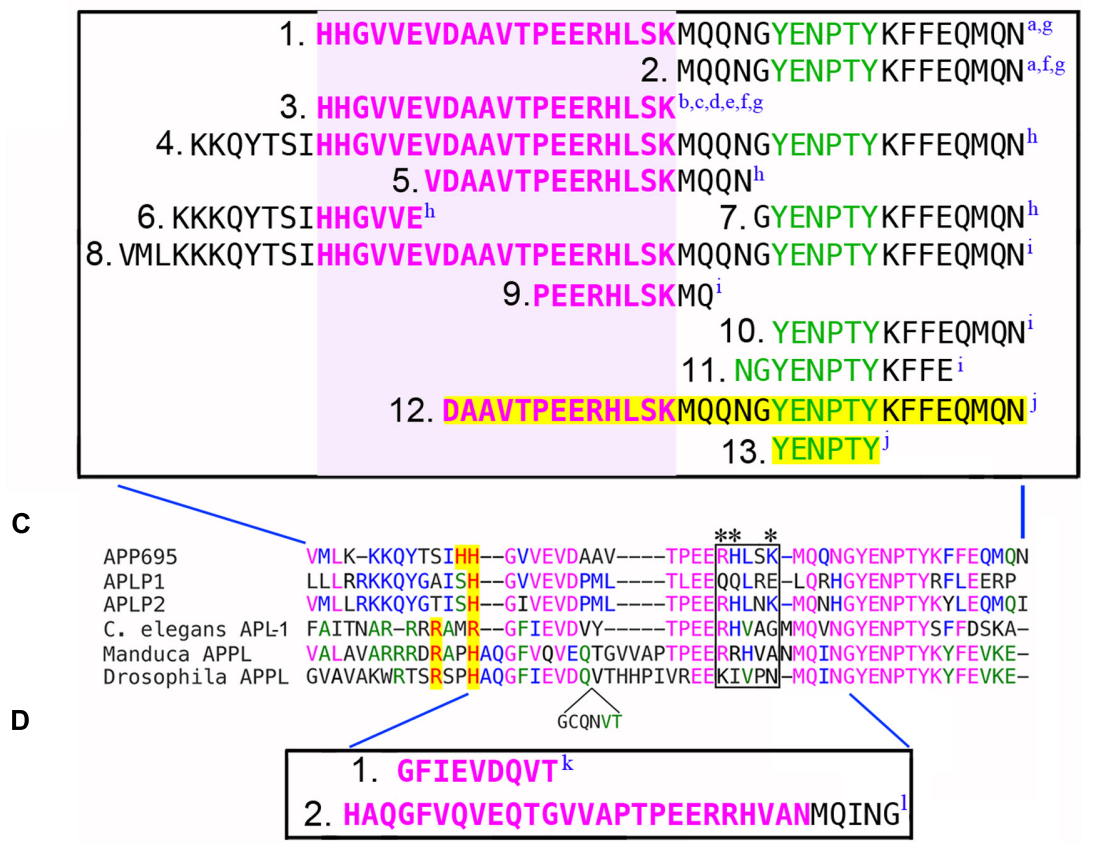

FIGURE 1 | Defining the G protein-binding domains in APP family proteins. (A) Intracellular domain of human APP 695 , equivalent to the cytoplasmic AICD fragment generated by $\gamma$-secretase processing. Magenta region indicates the "peptide 20 " Go binding domain $\left(H_{657}-L_{676}\right)$ originally identified by Nishimoto et al. (1993); green region indicates the tyrosine-based sorting motif (YENPTY) that mediates interactions with many other cytosolic proteins. Asterisks indicate the $\mathrm{N}$-terminal HH doublet in the Go domain, while the BBXXB motif (RHLSK) is located at the C-terminus (compare with C). (B) Summary of the deletions used by different investigators to map the sequences in APP that are required for its interaction with $\mathrm{G} \alpha \mathrm{O}$. Amino acids contained within the $\mathrm{G}$ protein-binding domain are highlighted in magenta; the YENPTY domain is highlighted in green. Deletions that eliminated $\mathrm{G} \alpha \mathrm{o}$ interactions $\left(1 \mathrm{~B}_{1}, 1 \mathrm{~B}_{3}, 1 \mathrm{~B}_{4}, 1 \mathrm{~B}_{5}, 1 \mathrm{~B}_{6}, 1 \mathrm{~B}_{8}, 1 \mathrm{~B}_{9}\right)$ encompassed some or all of the Go domain (indicated by light magenta box). Deletions that encompassed the YENPTY domain but not the Go domain did not affect Gao interactions $\left(1 \mathrm{~B}_{2}, 1 \mathrm{~B}_{7}, 1 \mathrm{~B}_{10}, 1 \mathrm{~B}_{11}\right)$. In one study, deletions highlighted in yellow $\left(1 \mathrm{~B}_{12}, 1 \mathrm{~B}_{13}\right)$ were found to interfere with APP-Gao signaling but paradoxically not with APP-Gao interactions. Superscripted letters indicate citations for each deletion construct (summarized below). (C) Amino acid alignment of the $\mathrm{G}$ protein-binding domains from human APP 695 , APLP1 and APLP2; plus APL-1 from Caenorhabditis elegans, APPL from Manduca sexta, and APPL from Drosophila melanogaster (which contains an additional inserted sequence; shown below the alignment). Identical amino acids are indicated by color. Basic amino acids in that align with (or near) the $\mathrm{HH}$ doublet in $\mathrm{APP}_{695}$ are highlighted in yellow. The boxed region indicates the BBXXB motif in APP 695 (RHLSK), and the equivalent region in other APP family proteins; only APLP2 also has a complete BBXXB motif (RHLNK). Asterisks indicate amino acids within the G protein-binding domains of APP 695 and APLP1 that were found to be necessary for interactions between membrane-tethered AICDs or CTF fragments of the holoproteins and Gas (Deyts et al., 2012).

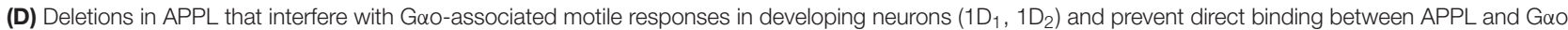

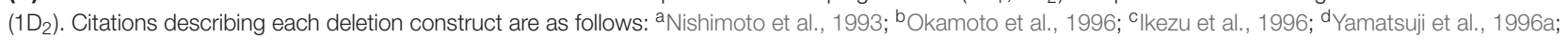

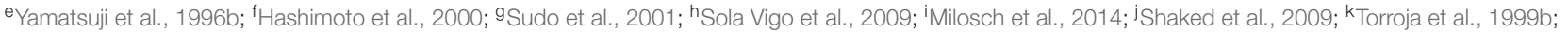
'Ramaker et al., 2013.

Yamatsuji et al. (1996a,b) used COS cells expressing Go to compare the responses elicited by wild type $\mathrm{APP}_{695}$ versus APP containing missense mutations that are known to cause early onset $\mathrm{FAD}$. In contrast to wild type $\mathrm{APP}_{695}$, expression of these "FAD-APP" mutant isoforms (including $\mathrm{V}_{642} \mathrm{I}, \mathrm{V}_{642} \mathrm{~F}$, $\mathrm{V}_{642} \mathrm{G}$ ) induced a dramatic increase in DNA fragmentation and apoptosis. This effect was blocked by PTX treatment (indicating $\mathrm{G} \alpha \mathrm{o} / \mathrm{i}$ proteins) or by expressing a dominant-interfering form of G $\alpha$ o (Table 1), but was not affected by CTX (an activator of Gas) and was absent in COS cells lacking Go. Notably, treatment with either synthetic $A \beta_{40}$ or $A \beta_{42}$ did not induce apoptotic responses in this assay, nor did conditioned medium harvested from cell cultures expressing the $\mathrm{V}_{642}$ mutant isoforms (which produce abundant $A \beta_{42}$ ). In combination, these studies supported the model that mutated forms of APP linked with FAD can indeed function as constitutively active Go-coupled receptors. Moreover, they suggested that the pathophysiological effects of FAD-APP mutations might be caused by aberrant hyperactivation of Go-dependent signaling, rather than simply promoting the accumulation of neurotoxic $\mathrm{A} \beta$. An appealing corollary to this model is that the downstream pathways regulated by Go could provide novel biomarkers or therapeutic targets for treating AD.

Unfortunately, attempts to identify these downstream pathways produced paradoxical results. For example, using COS cells co-expressing chimeric $\mathrm{G} \alpha$ subunits with different 
TABLE 1 | Evidence for functional interactions between APP family proteins and heterotrimeric $\mathrm{G}$ proteins.

\begin{tabular}{|c|c|c|}
\hline APP source & G-protein & Citation \\
\hline $\begin{array}{l}\text { APP }_{695} \text { wt; peptide } 20 \\
\left(\mathrm{H}_{657}-\mathrm{L}_{676}\right.\end{array}$ & $\begin{array}{l}\mathrm{G} \alpha \mathrm{O}^{*} ; \text { not } \mathrm{G} \alpha \mathrm{s} \\
\mathrm{G}_{\alpha i_{1,2,3}}\end{array}$ & Nishimoto et al., 1993 \\
\hline Peptide $20\left(\mathrm{H}_{657}-\mathrm{L}_{676}\right)$ & $\mathrm{G} \alpha \mathrm{O} / \mathrm{i} ; \underline{\text { not }} \mathrm{G} \alpha \mathrm{s}$ & $\begin{array}{l}\text { Colombo et al., 1994; } \\
\text { Lang et al., } 1995\end{array}$ \\
\hline $\mathrm{APP}_{695} \mathrm{wt}$ & $\mathrm{G} \alpha \mathrm{O}^{*} ; \underline{\text { not }} \mathrm{G}_{\alpha i_{2}}$ & Okamoto et al., 1995 \\
\hline $\mathrm{APP}_{695} \mathrm{wt}$ & $\mathrm{G} \propto \mathrm{O}^{*}$ & Okamoto et al., 1996 \\
\hline $\begin{array}{l}\mathrm{APP}_{695} \text { wt, } \mathrm{V}_{642} \mathrm{l} \\
\mathrm{V}_{642} \mathrm{~F}, \mathrm{~V}_{642} \mathrm{G}\end{array}$ & $\begin{array}{l}\mathrm{G} \alpha \mathrm{O}^{*} \# ; \text { not } \mathrm{G} \alpha \mathrm{s}, \mathrm{G} \alpha \mathrm{i}_{2}, \\
\mathrm{G} \alpha \mathrm{z}\end{array}$ & Ikezu et al., 1996 \\
\hline $\begin{array}{l}\mathrm{APP}_{695} \mathrm{~V}_{642} \mathrm{l}, \mathrm{V}_{642} \mathrm{~F} \\
\mathrm{~V}_{642} \mathrm{G}\end{array}$ & $\mathrm{G} \alpha \mathrm{O} ;$; $\underline{\text { not }} \mathrm{G}_{\alpha i_{2}}$ & Yamatsuji et al., 1996a \\
\hline $\begin{array}{l}\mathrm{APP}_{695} \mathrm{~V}_{642} \mathrm{l}, \mathrm{V}_{642} \mathrm{~F} \\
\mathrm{~V}_{642} \mathrm{G}\end{array}$ & $\mathrm{G} \alpha \mathrm{O} ; \underline{\text { not }} \mathrm{G}_{\alpha i_{2}}$ & Yamatsuji et al., 1996b \\
\hline $\mathrm{APP}_{695} \mathrm{~V}_{642} \mathrm{I}$ & GaO\#; $\underline{\text { not }} \mathrm{G} \alpha \mathrm{t}$ & Giambarella et al., 1997 \\
\hline $\mathrm{APP}_{695} \mathrm{wt}$ & 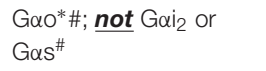 & Brouillet et al., 1999 \\
\hline $\mathrm{APP}_{695} \mathrm{~V}_{642} \mathrm{I}$ & $\mathrm{G} \alpha \mathrm{o} / \mathrm{i}^{\dagger}$ & Hashimoto et al., 2000 \\
\hline $\mathrm{APP}_{695}$ wt, $\mathrm{V}_{642} \mathrm{l}$ & $\mathrm{G} \alpha \mathrm{O} / \mathrm{i}^{\dagger}$ & Sudo et al., 2000 \\
\hline $\mathrm{APP}_{695}$ wt, $\mathrm{V}_{642} \mathrm{l}$ & $\mathrm{G} \alpha \mathrm{O} / \mathrm{i}^{\dagger}$ & Niikura et al., 2000 \\
\hline $\mathrm{APP}_{695} \mathrm{wt}$ & $\mathrm{G} \alpha \mathrm{O} / \mathrm{i}^{\dagger}$ & Mbebi et al., 2002 \\
\hline $\mathrm{APP}_{695} \mathrm{wt}$ & $\mathrm{G} \alpha \mathrm{O} ; \underline{\text { not }} \mathrm{G}_{\alpha i_{1}}$ & Hashimoto et al., 2003a \\
\hline EGFR-APP $_{\text {icd }}$ chimera & $\mathrm{G} \alpha \mathrm{O} / \mathrm{i}^{\dagger}$ & $\begin{array}{l}\text { Hashimoto et al., } \\
\text { 2003b }\end{array}$ \\
\hline $\begin{array}{l}\mathrm{APP}_{695} \mathrm{~V}_{642} \mathrm{I}, \mathrm{APP}_{695} \\
\mathrm{KM}_{595-6} \mathrm{NL}\end{array}$ & $\mathrm{G} \alpha \mathrm{O}$ & McPhie et al., 2003 \\
\hline $\mathrm{APP}_{695} \mathrm{wt}, \mathrm{V}_{642} \mathrm{I}$ & $\mathrm{G} \alpha \mathrm{O} / \mathrm{i}^{\dagger}$ & Niikura et al., 2004 \\
\hline $\mathrm{APP}_{695}$ wt & $\mathrm{G} \alpha \mathrm{O} / \mathrm{i}$ & Xu et al., 2009 \\
\hline $\mathrm{APP}_{695} \mathrm{wt}$ & $\mathrm{G} \alpha \mathrm{O} ; \underline{\text { not }} \mathrm{G} \alpha \mathrm{i}_{2}, \mathrm{G} \alpha \mathrm{i}_{3}$ & Sola Vigo et al., 2009 \\
\hline $\mathrm{APP}_{695} \mathrm{wt}$ & $\mathrm{G} \alpha \mathrm{O}^{\dagger}$ & Shaked et al., 2009 \\
\hline $\begin{array}{l}\text { APPL (Manduca, } \\
\text { Drosophila) }\end{array}$ & $\mathrm{G} \alpha \mathrm{O}^{*} ; \underline{\text { not }} \mathrm{G} \alpha \mathrm{i}, \mathrm{G} \alpha \mathrm{s}$ & Ramaker et al., 2013 \\
\hline $\mathrm{APP}_{695}$ wt & $\mathrm{G} \alpha \mathrm{O}^{*} ; \underline{\text { not }} \mathrm{G} \alpha \mathrm{S}$ & Ramaker et al., 2013 \\
\hline $\mathrm{APP}_{695} \mathrm{wt}$ & $\mathrm{G} \alpha 0^{*}$ & Fogel et al., 2014 \\
\hline $\mathrm{APP}_{695} \mathrm{wt}$ & $\mathrm{G} \alpha \mathrm{O} / \mathrm{i}^{\dagger}$ & Milosch et al., 2014 \\
\hline APPL (Manduca) & $\mathrm{G} \alpha \mathrm{O}$ & Ramaker et al., 2016a \\
\hline $\begin{array}{l}\text { Membrane-tethered } \\
\text { AICD }\end{array}$ & $\mathrm{G} \alpha \mathrm{s}^{* *}$ & Deyts et al., 2012 \\
\hline
\end{tabular}

Summary of published evidence that APP interacts with Gao (but usually not other $G$ proteins, including Gas, Gaz, and Gai isofroms). The table includes studies on both wild type APP 695 , isolated peptide 20 constructs (containing the $G$ protein-binding domain of $A P P_{695}$ ), and $F A D$-associated mutant forms of APP with altered residues at $V_{642}$ (indicated in the left-hand column). Studies that showed direct binding between Gao and APP/APPL are indicated with an asterisk $(*)$. Studies that used PTX to indicate the involvement of Gao/i family proteins are indicated with a cross (t). Studies that used CTX to indicate the absence of Gas-dependent signaling is indicated with a hash mark (\#). Study that showed direct binding between Gos and constructs containing the G proteinbinding domain is indicated with a double asterisk (**). Citations for each set of results are shown in the right-hand column. *Studies that showed direct binding between Gao and APP/APPL (or the G protein-binding domain). 'Studies that demonstrated sensitivity to PTX, indicating the involvement of Goo/i. \#Studies that tested sensitivity to CTX, indicating the absence of Gas-dependent signaling. ** Study that showed direct binding between Gas and peptides containing the G protein-binding domain.

variants of APP, Ikezu et al. (1996) found that FAD-APP isoforms inhibited cAMP response element (CRE)-mediated transcription in a G $\alpha$ o-specific manner. Curiously, this effect was independent of adenylyl cyclase (AC) activity, while inhibitors of G $\beta \gamma$ signaling (rather than G $\alpha$ o) blocked apoptotic responses in this assay (Giambarella et al., 1997). From these studies, the authors concluded that APP signaling normally regulates both

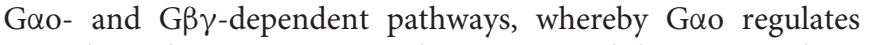
CRE-dependent transcriptional responses, while G $\beta \gamma$ regulates other effectors (as yet undefined) that can induce apoptosis when chronically activated. More perplexing were the results from another group, who found that 22C11 treatment in brain membrane fractions actually inhibited Gao-dependent responses (Brouillet et al., 1999), leading to the proposal that unknown proteins expressed by neurons but not glial-derived cells (or in reconstituted membranes) might regulate G $\alpha$ o activation by APP (Brouillet et al., 1999; Sudo et al., 2000). How the misregulation of G $\alpha$ o- versus G $\beta \gamma$-dependent pathways might contribute to $\mathrm{AD}$ remained an open question.

\section{NEUROTOXIC MECHANISMS OF MISREGULATED APP- G $\alpha \circ$ SIGNALING: CONFLICTING MODELS}

Subsequent investigations have generated an unexpectedly complicated (and often contradictory) view of how the APPGo pathway might function in the diseased nervous system. Using a variety of transfected cell lines, Nishimoto et al. (1993) first confirmed that the induction of APP-Gao signaling (by antibody crosslinking or induced dimerization) required transmembrane APP (Sudo et al., 2000; Hashimoto et al., 2003a), and that hyperactivation of this pathway could induce apoptotic responses in cultured mouse neurons (see also Rohn et al., 2000). Both groups described classic features of neuronal apoptosis in their assays, including neurite degeneration, nuclear condensation, internucleosomal DNA cleavage, and activation of pro-apoptotic caspases (including caspase 3, 7, and 9). Treatment with inhibitors of glutathione metabolism or NADPH oxidase (as well as incubation with antioxidants) effectively blocked the cell death response, suggesting that hyperstimulation of the APP-Gao pathway induces a chronic elevation of reactive oxygen species (ROS), resulting in the induction of caspasedependent apoptosis. Moreover, expressing FAD-APP isoforms induced the same cytotoxic responses caused by hyperstimulating wild type APP, including activation of ASK1 (Apoptosis SignalRegulating kinase) and its downstream effector JNK that resulted in chronic upregulation of NADPH oxidase, elevated ROS levels, and activation of pro-apoptotic caspases (Hashimoto et al., 2003b; Niikura et al., 2004). A similar response could be induced by expressing a chimeric protein containing the dimerization domain of the EGF receptor fused with the APP cytoplasmic domain, providing a plausible explanation for how the hyperstimulation of normal APP-Go signaling with crosslinking antibodies could provoke neuronal death in an $\mathrm{A} \beta$-independent manner. By comparison, the neurotoxic effects of FAD-associated mutations within a different region of APP $\left(\mathrm{K}_{595} / \mathrm{M}_{596}\right)$ were found to be independent of Go, suggesting that different disease-associated mutations in APP might perturb a variety of signaling pathways that affect neuronal viability (Hashimoto et al., 2000). Collectively, these results bolstered the 
argument that the aberrant APP-Go signaling might contribute to both late-onset $\mathrm{AD}$ and some forms of FAD.

However, it should be noted that enforced dimerization of APP (with crosslinked antibodies or chimeric fusion proteins) involves rather artificial methods that may not recapitulate authentic physiological or pathophysiological interactions. Moreover, it is difficult to reconcile these results with more recent evidence that $\sim 65 \%$ of membrane-bound APP in healthy cells is normally present in a dimeric configuration (Gralle et al., 2009). Nevertheless, these cytotoxic effects could be recapitulated by overexpressing an FAD-APP isoform $\left(\mathrm{V}_{642} \mathrm{I}-\mathrm{APP}\right)$ in both neuroblastoma cells and primary neurons (Niikura et al., 2000, 2004), independent of $A \beta$-associated toxicity (Sudo et al., 2001). Alternatively, other groups have suggested that forced dimerization of APP might provoke Go-dependent apoptotic responses via a variety of other pathways, including PAK3-dependent re-entry into the cell cycle (McPhie et al., 2003), misregulation of Src-dependent actin dynamics and focal adhesion turnover (Xu et al., 2009), and calpain/calcineurin-dependent proteolysis of CaMKIV, resulting in the misregulation of CREB (Mbebi et al., 2002). Also problematic is the mechanism by which the APP-Go pathway might actually stimulate JNK: although both the $\alpha$ and $\beta \gamma$ subunits of a number of heterotrimeric G proteins (including Go) can modulate JNK activity in different contexts, these responses typically require a cascade of other kinases and adapter proteins that have not been implicated in APP-Go signaling (Goldsmith and Dhanasekaran, 2007; Bromberg et al., 2008; Yu et al., 2016). Lastly, all of these studies focused on pathological outcomes that could be induced by aberrant APP-G $\alpha$ o signaling, but the authentic functions of this pathway in the healthy nervous system remained largely unexplored. As described below, recent studies from the Kögel laboratory have now indicated that APP-G $\alpha$ o signaling may actually antagonize the JNK pathway under physiological conditions, whereby the induction of APP signaling counteracts cellular stress responses via the PI3K cascade, providing a mechanism that promotes neuronal survival (Kögel et al., 2012; Milosch et al., 2014).

\section{IS APP-G $\alpha$ O SIGNALING ALTERED IN HUMAN PATIENTS WITH AD?}

Whether the misregulation of APP-Go signaling actually plays a role in provoking $\mathrm{AD}$ remains unknown. However, a variety of studies have offered intriguing hints that support this hypothesis. Initial reports using human brain samples revealed that the expression patterns of many heterotrimeric $G$ proteins are altered in late sporadic $\mathrm{AD}$, particularly within the most vulnerable brain regions (including cortex and hippocampus). These changes also correlate with a general reduction in G protein-dependent GTP hydrolysis at stages that precede the onset of clinical disease (O'Neill et al., 1994; Cowburn et al., 2001; Garcia-Jimenez et al., 2002). Similarly, using reconstituted membrane preparations from human brain samples, Mahlapuu et al. (2003) found that the induction of G protein activity by APP-derived peptides was significantly reduced in postmortem elderly AD patients compared to age-matched controls. Recapitulating the original studies by Nishimoto et al. (1993), they also found that membrane-tethered constructs of the Go domain (peptide 20 plus the transmembrane $\mathrm{T}_{639}-\mathrm{L}_{649}$ sequence) induced more robust $\left[{ }^{35} \mathrm{~S}\right] \mathrm{GTP} \gamma \mathrm{S}$ binding than soluble peptide 20 (Mahlapuu et al., 2003). Curiously, adding the transmembrane peptide alone $\left(\mathrm{T}_{639}-\mathrm{L}_{649}\right)$ also affected $\left[{ }^{35} \mathrm{~S}\right] \mathrm{GTP} \gamma \mathrm{S}$ binding, while equivalent peptides containing $\mathrm{V}_{642}$ APP-FAD mutations were even more effective (Karelson et al., 2005), although how these hydrophobic constructs might interact with $G$ proteins when applied to isolated membranes is unclear. Nevertheless, these results provided indirect evidence that disease-associated changes in the GPCR-like function of APP might contribute to both FAD and late-onset $\mathrm{AD}$ (as noted by the authors).

Perhaps because it is the most abundant G protein in the brain (Strittmatter et al., 1990; Jiang and Bajpayee, 2009), the overall levels of $\mathrm{G} \alpha \mathrm{o}$ do not appear to be altered in either FAD or late-onset sporadic AD (O'Neill et al., 1994; Shaked et al., 2009), but several studies suggest that Goospecific responses are progressively disrupted in both familial and late sporadic forms of the disease. For example, using membrane preparations from human brain samples, Reis et al. (2007) found that the effects of FAD-APP-derived peptides on G protein activity were blocked by PTX, while another report showed that $A \beta$ peptides could activate $G \alpha o$ in lipid vesicles (Rymer and Good, 2001), although it is unclear whether the topology of these assays recapitulates authentic $\mathrm{G} \alpha \mathrm{o}-\mathrm{A} \beta$ interactions. More compelling are two studies showing that APP-Go signaling might be directly altered by neurotoxic A $\beta$ in neurons. Based on previous evidence that APP can bind neurotoxic A $\beta$ fibrils (Lorenzo et al., 2000; Van Nostrand et al., 2002), Lorenzo et al. (2000) also showed that APP overexpression rendered hippocampal neurons more vulnerable to $A \beta$-induced degeneration, an effect that was abrogated by deletion of the Go-binding domain in APP or treatment with PTX (Sola Vigo et al., 2009). Notably, expressing a PTX-insensitive form of $G \alpha o$ restored the toxic effects of $A \beta$ treatment, but only in the presence of an intact Go-binding domain. Subsequent work by Masliah and colleagues demonstrated that treatment with $A \beta$ reduced APP-G $\alpha$ o interactions (corresponding to Go activation) and induced cell death in transfected neuroblastoma lines, and again this effect was PTX-dependent (Shaked et al., 2009). $\mathrm{A} \beta$ treatment also provoked a significant increase in calcium $\left(\mathrm{Ca}^{2+}\right)$ influx in a Go-dependent manner, consistent with earlier studies suggesting that hyperactivation of APP signaling could provoke $\mathrm{Ca}^{2+}$ overload and cell death. Most notably, they showed that APP-G $\alpha$ o interactions declined in patients suffering from progressive stages of $\mathrm{AD}$, corresponding to an overall increase in $\mathrm{G}$ protein activation (though not specifically $\mathrm{G} \alpha \mathrm{o}$ ).

In the course of their cell culture assays, the authors found that mutating a particular residue within the cytoplasmic domain of APP $\left(D_{664} A\right)$ blocked the ability of $A \beta$ to affect APP-G $\alpha$ o interactions (Shaked et al., 2009). Noting that this residue is required for caspase-dependent cleavage of APP to generate a cytotoxic C31 fragment ( $\mathrm{Lu}$ et al., 2003), they proposed a mechanism by which $\mathrm{A} \beta$ binding induces caspase-dependent 
cleavage of APP, resulting in the release of a C31-Go complex that could stimulate $\mathrm{G} \alpha \mathrm{o}$ in some undefined fashion. However, other investigators have noted that the $\mathrm{D}_{664} \mathrm{~A}$ mutation (located within the Go domain) is equally likely to disrupt interactions between APP and other cytoplasmic proteins (Galvan et al., 2007), the most obvious candidate being Gao. Thus, mutations at this site might perturb key structural features that permit APP to function as a Go-coupled receptor, although the steric rearrangements that lead to the activation of G $\alpha$ o remain unexplored. Paradoxically, Shaked et al. (2009) also reported that deletion of the C-terminal YENPTY domain mitigated the effects of $A \beta$ on G $\alpha$ o activation, contradicting several previous studies demonstrating that this motif is not required for direct interactions between APP and Gao (Nishimoto et al., 1993; Kawasumi et al., 2004; King and Scott Turner, 2004; Sola Vigo et al., 2009). Nevertheless, these results offered the most compelling evidence that APPGo signaling is altered over the course of $\mathrm{AD}$, consistent with the model that elevated $A \beta$ might induce the aberrant activation of Gao-dependent pathways that provoke neuropathological responses.

Recently, Fogel et al. (2014) used fluorescence resonance energy transfer (FRET)-based protocols to demonstrate a close association between APP and G $\alpha$ o that was modulated by APP activation. They also showed that $A \beta_{40}$ induced structural rearrangements in the presynaptic APP/Go complex by promoting APP dimerization, which in turn resulted in G protein-dependent $\mathrm{Ca}^{2+}$ influx and glutamate release (Fogel et al., 2014). Both aspects of this response were found to critically involve the E1 extracellular domain of APP, suggesting that $A \beta_{40}$ can mimic the effects of endogenous ligands. Based on these findings, the authors proposed that excessive APP activation by amyloid peptides might contribute to hippocampal hyperactivity under pathological conditions, supporting the hypothesis that normal APP-Gao interactions are altered in AD. An added dimension to this model is that Goo may also functionally interact with presenilins, essential components of the $\gamma$-secretase complex that are involved in generating $A \beta$ peptides and AICD fragments and are also mutated in some forms of FAD (Walter et al., 2001; Jayne et al., 2016). For example, Smine et al. (1998) showed that presenilin-1 (PS-

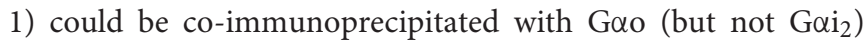
when overexpressed in COS-7 cells, and that a C-terminal fragment (CTF) of PS- 1 could activate Gao (but not ${\mathrm{G} \alpha i_{2}}_{2}$ ) in a PTX-sensitive manner. Likewise, overexpressing FAD mutant forms of Presenilin-2 (PS-2) in neuroblastoma cells induced apoptotic responses that were inhibited by PTX and restored

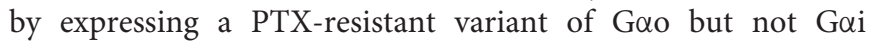
(Wolozin et al., 1996; Abe et al., 2004). Whether presenilins actually modulate $\mathrm{G} \alpha \mathrm{o}$-dependent pathways in neurons and how this might affect APP-G $\alpha$ o interactions remains to be explored. Nevertheless, it is possible that multiple factors associated with $\mathrm{AD}$ might contribute to the pathological misregulation of APP-G $\alpha_{0}$ signaling (including FAD-linked mutations in both APP and the presenilins), as well as the accumulation of neurotoxic amyloid peptides that can hyperactivate this pathway.

\section{STRUCTURE, SPECIFICITY, AND EVOLUTIONARY CONSERVATION OF THE Go-BINDING DOMAIN IN APP FAMILY PROTEINS}

As noted earlier, Nishimoto et al. (1993) first identified the G protein-binding domain in APP, based on their previous discoveries that several type- 1 transmembrane proteins directly bind $G \alpha$ subunits via short peptide sequences containing BBXB or BBXXB motifs, where $\mathrm{B}$ is a basic amino acid residue and $\mathrm{X}$ is any non-basic residue (Okamoto et al., 1990, 1991; Okamoto and Nishimoto, 1992). From this analysis, they identified "peptide 20 " in $\mathrm{APP}_{695}\left(\mathrm{H}_{657}-\mathrm{L}_{676}\right)$, which contains two N-terminal basic residues $(\mathrm{HH})$ and terminates in a BBXXB motif (Figure 1A; magenta region). In a meticulous series of experiments using reconstituted liposomes and isolated membrane fractions, they then showed that this "peptide 20" domain (subsequently designated the Go activator domain) was both necessary and sufficient for directly binding and activating $\mathrm{G} \alpha \mathrm{o}$, but not $\mathrm{G} \alpha$,

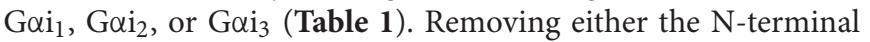
histidines (Figure 1A, asterisks) or the C-terminal BBXXB motif from peptide 20 (RHLSK) greatly attenuated its ability to simulate G $\alpha$ o in GTPase activation assays, although membrane-tethered versions of the Go domain were considerably more potent than soluble forms. Thirdly, they demonstrated that interactions between full-length APP and G $\alpha$ o required this domain: a deletion that removed both the Go domain and the C-terminal YENPTY motif precluded APP-G $\alpha$ o interactions $\left(\mathrm{His}_{657}-\mathrm{N}_{695}\right.$; Figure $\mathbf{1 B}_{1}$ ), whereas a deletion encompassing only the YENPTY did not (Figure $\mathbf{1 B}_{2}$ ). These results provide strong evidence that the juxtamembrane $G$ protein-binding domain in APP promotes functional interactions with $G \alpha o$ but not other $G$ proteins (Nishimoto et al., 1993).

Using similar methods, Nishimoto et al. (1993) subsequently showed that full-length APP binds and stimulates Goo (but not $\mathrm{G}_{2} \mathrm{i}_{2}$ ) following antibody activation in reconstituted vesicles (Okamoto et al., 1995; Ikezu et al., 1996), while the apoptotic effects of FAD-APP isoforms (mutated at $\mathrm{V}_{642}$ ) were both PTXsensitive and required the Go domain: FAD-APP constructs lacking only the Go domain (Figure $\mathbf{1 B}_{3}$ ) failed to induce G $\alpha$ odependent cytotoxic responses, whereas deletions encompassing the YENPTY domain (Figure $\mathbf{1 B}_{2}$ ) had no effect (Okamoto et al., 1996; Yamatsuji et al., 1996a; Hashimoto et al., 2000; Niikura et al., 2000; Sudo et al., 2001). This apoptotic response could also be blocked with dominant-interfering forms of

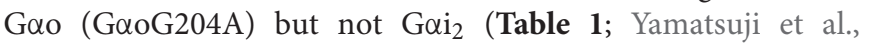
1996b). Using Myc-tagged constructs for in vitro pull-down assays, Brouillet et al. (1999) subsequently confirmed that the cytoplasmic domain of APP could bind $\mathrm{G} \alpha$ o but not $\mathrm{G} \alpha \alpha_{\mathrm{i} 2}$, and that this interaction was reduced when the $\mathrm{N}$-terminal $\mathrm{H}_{657} \mathrm{H}_{658}$ doublet was replaced with hydrophobic residues. Sudo et al. (2001) and Hashimoto et al. (2003a) then showed that that apoptotic effects of APP stimulation were prevented by deleting the Go interaction domain (Figure $\mathbf{1 B}_{3}$ ) but not the YENPTY domain (Figure $\mathbf{1 B}_{2}$ ), and that they were mediated specifically by Goo but not Gai. Similarly, based 
on evidence that $A \beta$ might induce neurotoxic responses via the APP-G $\alpha$ o pathway, Lorenzo and colleagues showed that this effect also required the Go domain (Sola Vigo et al., 2009): deleting the entire cytoplasmic domain (Figure $\mathbf{1 B}_{4}$ ) precluded the activation of $\mathrm{G} \alpha \mathrm{o}$-dependent responses to $\mathrm{A} \beta$, as did complementary deletions targeting different portions of the Go domain (Figure $\mathbf{1 B}_{5,6}$ ), whereas a deletion encompassing the YENPTY motif did not (Figure $\mathbf{1 B}_{7}$ ). In a more physiological context, the Kögel group recently demonstrated the importance of the Go domain in mediating APP-dependent neuroprotective responses to SAPP $\alpha$ : a deletion that removed the conserved PEERH motif within this domain (Figure $\mathbf{1 B}_{9}$ ) prevented APPdependent signaling that was also blocked by PTX (implicating G $\alpha$ o/i proteins), whereas two different deletions targeting the YENPTY motif (Figure $\mathbf{1 B}_{10}, 11$ ) had no effect (as summarized below).

In contrast to the foregoing studies, Shaked et al. (2009) reported that $\mathrm{G} \alpha \mathrm{o}$ could still be co-immunoprecipitated with APP lacking the C31 cytoplasmic region (including both the Go-binding domain and the YENPTY motif; Figure $\mathbf{1 B}_{12}$ ), but that deleting this region prevented APPdependent activation of G $\alpha$ o pathways in cell culture. They also found that over-expressed C99 fragments could be co-immunoprecipitated with Gao (the only report of this interaction). Curiously, deletion of only the YENPTY motif (Figure $\mathbf{1 B}_{13}$ ) also blocked Gao-dependent responses in this assay, in contrast to many other studies demonstrating that this domain is not required for APP-G $\alpha$ o interactions. Based on these observations, the authors postulated that the transduction of APP-Gao signaling might involve the YENPTY motif as well as the Go domain (either directly or indirectly), possibly in response to $A \beta$-induced cleavage of APP (Shaked et al., 2009). Whether this response also involves internalization responses mediated by the YENPTY motif remains to be explored (cf. Lai et al., 1995; Deyts et al., 2016b).

Other members of the APP family also contain Go-like domains, albeit with some sequence variations (Figure 1C). Both APLP1 and APLP2 contain only one N-terminal histidine that aligns with the $\mathrm{HH}$ doublet in $\mathrm{APP}_{695}$ (highlighted in yellow), and only APLP2 also possesses an intact C-terminal BBXXB motif (boxed region). As summarized above, only $\mathrm{APP}_{695}$ has been shown to activate $\mathrm{G} \alpha \mathrm{O}$, although a rigorous analysis of potential interactions between APLP1/2 and G $\alpha$ o has not been conducted in vivo. Likewise, the Go domains in both nematode APL-1 and insect APPL contain only a single N-terminal histidine and lack complete BBXXB motifs. Nevertheless, studies in several insect models have shown that APPL does functionally interact with $\mathrm{G} \alpha$ o both in vitro and in vivo, whereby deleting different portions of the Go domain in APPL (Figure $\mathbf{1 D}_{1,2}$ ) disrupted Goo-associated responses in the developing nervous system (Torroja et al., 1999b; Ramaker et al., 2013; and described below). How these structural variations within the Go domain might affect the dynamics of Goo activation/inactivation under physiological conditions remains to be explored.

\section{PHYSIOLOGICAL ROLE OF APP-G $\alpha O$ INTERACTIONS IN STRESS SIGNALING AND NEUROPROTECTION}

Based on early work suggesting that APP might regulate both cell adhesion and excitoprotective responses (Mattson et al., 1993; Schubert and Behl, 1993), a variety of in vitro and in vivo assays demonstrated that both full-length APP and its $\operatorname{APP} \alpha$ ectodomain fragments (produced by $\alpha$-secretase cleavage) could have potent neuroprotective activity under different conditions (reviewed in Kögel et al., 2012; Nhan et al., 2015). For example, deletion of the sole APP ortholog in nematode (APL-1) caused larval lethality that could be rescued by expressing extracellular domain fragments equivalent to sAPP $\alpha$ (Hornsten et al., 2007; Ewald et al., 2016), while overexpressing sAPP $\alpha$ rescued some behavioral deficits in mice lacking members of the APP family (Ring et al., 2007; Weyer et al., 2011). From these and other experiments emerged a complex scenario whereby both APP and $\operatorname{sAPP} \alpha$ might independently confer beneficial responses under physiological conditions. However, elevated sAPP $\alpha$ levels can also have unwanted effects on cell proliferation and tumorigenesis, potentially due to interactions with receptors whose roles in neuroprotection is unclear (Adlerz et al., 2007; Zhou et al., 2011). More recently, Kögel and colleagues have provided new evidence that transmembrane APP and $\operatorname{sPP} \alpha$ interact as a ligand/receptor pair in neurons to modulate stress signaling, via activation of the pro-survival PI3K/Akt pathway (Milosch et al., 2014). Using a variety of experimental strategies, they demonstrated that both APP and sAPP $\alpha$ antagonize the activation of the JNK-dependent stress signaling pathway, which (as noted earlier) is a key upstream modulator of mitochondriadependent apoptosis (Kögel et al., 2005; Copanaki et al., 2010; Eckert et al., 2011). Conversely, several groups have now shown that the protective function of APP requires activation of the PI3K/Akt pathway (Cheng et al., 2002; Copanaki et al., 2010; Eckert et al., 2011; Jimenez et al., 2011). Since Akt negatively regulates several JNK-activating kinases, including ASK1 and mixed lineage kinase 3 (MLK3), these findings suggest that APP modulates a dynamic interplay between stress and survival pathways (Kögel et al., 2012).

To define the role of full-length APP in this response, Milosch et al. (2014) showed that the protective effects of both sAPP $\alpha$ and a recombinant fragment containing only the E1 domain of APP were completely abrogated in neurons from APP knockout animals or in APP-depleted SH-SY5Y cells. These results clearly demonstrated that expression of membrane-bound holo-APP was required for $\mathrm{APP} \alpha$-dependent Akt activation and neuroprotection in these assays, supported by other evidence that sAPP $\alpha$ can regulate the dimerization of transmembrane APP in cell culture (Gralle et al., 2009; Kaden et al., 2012). Likewise, studies in Drosophila have shown that sAPPL ectodomain fragments (equivalent to sAPP $\alpha$ ) bind full-length APPL, and that the neuroprotective effects of sAPPL require the presence of the holoprotein (Wentzell et al., 2012). More recently, a behavioral analysis demonstrated that full-length APPL and secreted sAPPL $\alpha$ act together to promote memory formation in 
adult Drosophila (Bourdet et al., 2015), consistent with the model that APP-sAPP $\alpha$ interactions may serve a variety of physiological functions in the nervous system.

Although the foregoing experiments demonstrated that the C-terminal domain of APP was required for the neuroprotective effects of the holoprotein, the last 15 amino acids were dispensable (as summarized in Figure $\mathbf{1 B}_{8-11}$ ): sAPP $\alpha$-dependent activation of Akt was unaffected in neurons from APP- $\triangle$ CT15 mice, which express a mutant form of APP lacking the cytoplasmic YENPTY motif (Milosch et al., 2014). As noted in other reviews, this domain mediates interactions with a plethora of cytoplasmic proteins but not Gao (Nishimoto et al., 1993; King and Scott Turner, 2004; Sola Vigo et al., 2009). To further map the specific regions in APP that are required for this activity, APP-KO cells were transfected with an APP construct lacking the PEER motif within its Go-binding domain ( $\triangle \mathrm{PEERH})$. In contrast to the YENPTY mutant, the $\triangle \mathrm{PEERH}$ mutant did not rescue sAPP $\alpha$-induced Akt activation following trophic factor deprivation. In addition, treatment with PTX completely abolished the ability of $\operatorname{sAPP} \alpha$ to promote Akt activation and cell survival, further implicating a role for Go in this response. Lastly, activation of the PI3K/Akt pathway by sAPP $\alpha$ induced the phosphorylation of glycogen synthase kinase $3 \beta$ (GSK3 $\beta)$, which is a well-known mechanism for inhibiting GSK3 $\beta$-induced apoptotic responses (Watcharasit et al., 2003; Hanumanthappa et al., 2014). Whereas PI3K/Akt signaling was originally linked with receptor tyrosine kinase activation, numerous studies have shown that heterotrimeric $G$ proteins also play a critical role in regulating PI3K activity under both physiological and pathological conditions (Murga et al., 1998; Murga et al., 2000; New and Wong, 2007; Yanamadala et al., 2009). Since PTX selectively inhibits members of the Gao/i family, while APP only interacts with Gao and potentially G $\alpha$ s (as noted below), these results argue that APP/sAPP $\alpha$ interactions induce the PI3K/Akt pathway specifically via Goo.

Based on these findings, we propose that transmembrane APP mediates sAPP $\alpha$-induced neuroprotection via G $\alpha$ o-coupled activation of the PI3K/Akt pro-survival pathway (Figure 2A). In turn, activation of Akt phosphorylates and inhibits GSK3 $\beta$, as well as other pro-apoptotic targets (Datta et al., 1997; Endo et al., 2006; Jover-Mengual et al., 2010). We also propose that this response requires direct interactions between $\mathrm{SAPP} \alpha$ and holoAPP as a ligand-receptor pair. These results offer a resolution to paradoxical findings from previous investigations, demonstrating that holo-APP and $\mathrm{sAPP} \alpha$ are equally important in mediating neuroprotective responses. Conversely, factors that interfere with this function would render neurons more susceptible to cellular stress during brain aging and AD. The model that APP-G $\alpha$ o signaling serves a neuroprotective function under physiological conditions contrasts with the cytotoxic response elicited by hyperactivating this pathway in $\mathrm{AD}$ models (as summarized above). Of note is that treatment with $A \beta$ might also interfere with the neuroprotective effects of $\operatorname{sAPP} \alpha$, resulting in the disinhibition of GSK $3 \beta$ and consequent upregulation of apoptotic pathways (Jimenez et al., 2011). Since GSK3 $\beta$ activity is increased in the AD brain (Crews and Masliah, 2010; Jimenez et al., 2011; Llorens-Martin et al., 2014), we hypothesize that the decline in $\operatorname{sAPP} \alpha$ levels associated with both sporadic $\mathrm{AD}$ and FAD contributes to this phenomenon (Almkvist et al., 1997; Sennvik et al., 2000), thereby promoting tau hyperphosphorylation (Deng et al., 2015) and sensitizing neurons to stress and apoptosis. In summary, these studies provide new insight into the mechanisms by which APP-Go signaling regulates neuronal stress responses under physiological conditions, and how the loss of this function might render neurons more susceptible to cellular stress during normal brain aging and $\mathrm{AD}$.

\section{APP-G $\alpha$ O SIGNALING IN THE CONTROL OF NEURONAL MOTILITY: VIEWS FROM A NON-MAMMALIAN SYSTEM}

Although APP was originally identified in humans, it is actually a member of an evolutionarily ancient family of proteins that may serve similar roles in the developing nervous systems of many organisms (Coulson et al., 2000; Ewald and Li, 2012; Lazarov and Demars, 2012; Shariati and De Strooper, 2013). Studies using a variety of insect models have shown that APPL shares both structural and functional conservation with human $\mathrm{APP}_{695}$, including homologous extracellular and intracellular motifs that regulate interactions with other proteins (Cassar and Kretzschmar, 2016). In particular, several groups have demonstrated a role for APPL-G $\alpha$ o signaling in neuronal development. Using genetic methods, Torroja et al. (1996, 1999a) first showed that APPL plays an important role in regulating neuronal growth and maturation, and that this activity requires the conserved Go-binding domain shared by $\mathrm{APP}_{695}$ and APPL. Replacing endogenous APPL with a mutant form lacking this domain (Figure $\mathbf{1 D}_{1}$ ) disrupted the normal maturation of synaptic boutons at the neuromuscular junction, potentially caused by the loss of ligand-dependent APPL-Go signaling (Torroja et al., 1999b). Subsequent investigations into this response suggested a role for the homophilic cell adhesion receptor Fasciclin II (Fas II; the insect ortholog of NCAM), whereby trans-synaptic interactions mediated by Fas II could promote APPL signaling, in part via the activation of Goo. Whether Fas II acts as a ligand as well as a co-receptor for APPL remains to be explored, as does the role of downstream Gao effectors in regulating synaptic maturation. Nevertheless, this work offered compelling evidence that the APP-Go pathway is conserved in both invertebrate and vertebrate nervous systems.

Using Manduca sexta (tobacco hornworm) as a complementary model, the Copenhaver laboratory has also explored the role of APPL-Goo signaling in the developmental control of neuronal motility. Unlike Drosophila, the formation of the embryonic nervous system in Manduca involves an extended period of neuronal migration (Copenhaver and Taghert, 1989; Copenhaver, 2007), analogous to the more complex waves of migration that typify mammalian brain development (Ayala et al., 2007; Tabata and Nagata, 2016). Notably, APPL colocalizes with G $\alpha$ o in the leading processes and growing axons of migratory neurons in Manduca (Swanson et al., 2005), similar to the colocalization of APP and Gao in cultured mammalian neurons (Ramaker et al., 2013). 


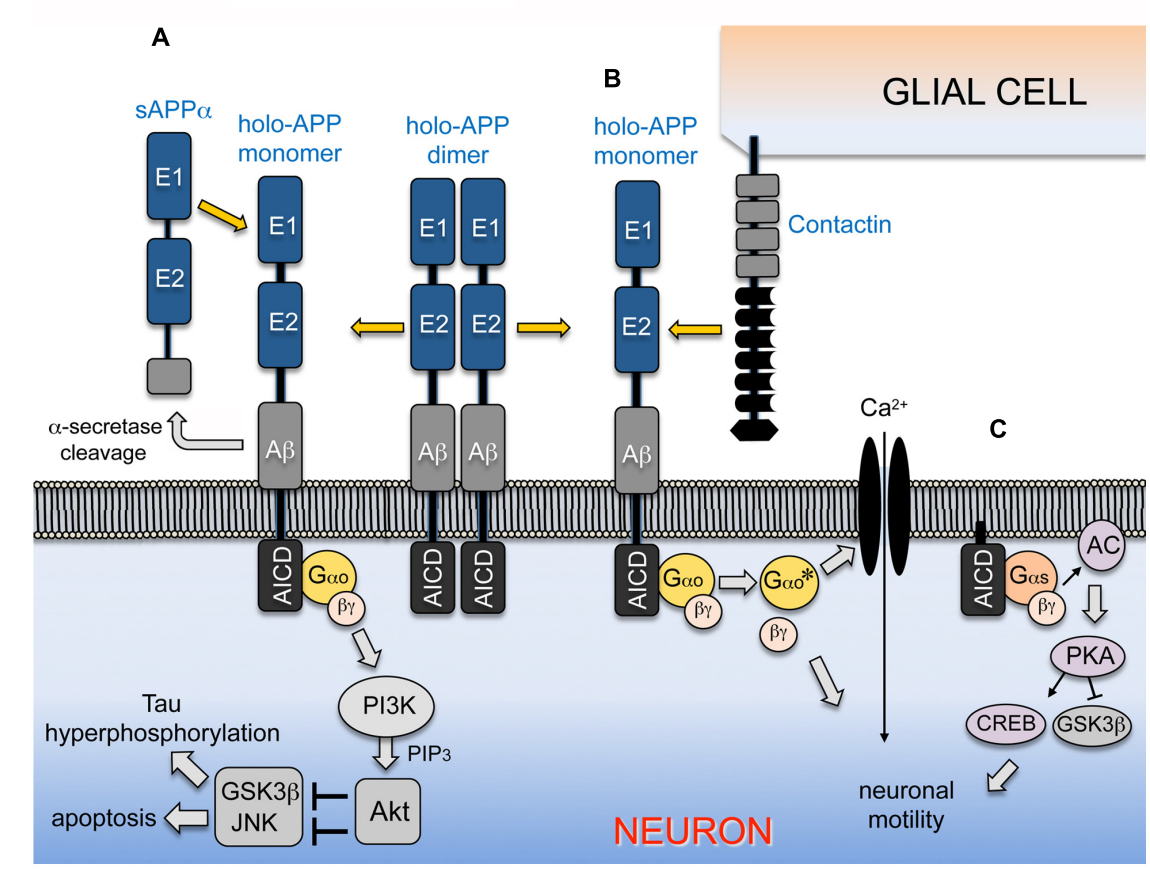

FIGURE 2 | APP-Go signaling can regulate alternative downstream pathways in a context-dependent manner. (A) APP is inserted into the plasma membrane of neurons as a type- 1 transmembrane protein that directly interacts with the heterotrimeric G protein Go; the major fraction of the holoprotein spontaneously forms homodimers under unstimulated conditions. Interactions with sAPP $\alpha$ ectodomain fragments (generated by $\alpha$-secretase processing) promotes

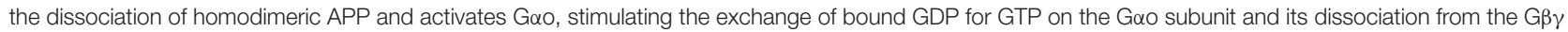
dimer (similar to signaling by conventional GPCRs; Fogel et al., 2014). Both activated Goo and G $\beta \gamma$ may stimulate PI3K, which then phosphorylates and activates Akt. In turn, Akt phosphorylates and inhibits downstream targets linked with apoptotic responses and Tau hyperphosphorylation, including GSK3 $\beta$ and components of the stress kinase pathway that regulate JNK (Kögel et al., 2003; Copanaki et al., 2010). In this manner, stimulation of the APP-G $\alpha$ o pathway by sAPP $\alpha$ promotes neuroprotective responses by modulating neuronal stress signaling, providing a mechanism for integrating the stress and survival responses regulated by APP and its cleaved sAPP $\alpha$ ectodomain fragments (Kögel et al., 2012; Milosch et al., 2014). (B) In the developing nervous system of Manduca, migratory neurons co-express insect APP (APPL) and Goo in their leading processes (Swanson et al., 2005; Ramaker et al., 2013), while their ensheathing glial cells express a single Contactin ortholog (MsContactin). Embryo culture assays have shown that glial Contactin stimulates APP-Go signaling in the migratory neurons, whereby Gao-dependent induction of $\mathrm{Ca}^{2+}$ currents (and possibly other effectors regulated by via $\mathrm{G} \beta \gamma$ ) induces local retraction responses that prevent ectopic migration and outgrowth (Horgan and Copenhaver, 1998; Ramaker et al., 2016b). (C) Membrane-tethered AICDs and APP-CTFs can also interact with Gas to stimulate neuronal motility and outgrowth, via a pathway that involves the activation of adenylate cyclase/cAMP/PKA/CREB signaling, accompanied by the phosphorylation/inactivation of GSK3 $\beta$ (Deyts et al., 2012, 2016a). Stimulation of APP signaling by different combinations of ligands and co-receptors might preferentially activate Gao- or Gas- associated responses in a context-dependent manner, whereby APP-G protein signaling can either promote or inhibit neuronal motility at specific stages and locations in the nervous system.

In addition, co-immunoprecipitation assays showed that endogenously expressed APPL and Goo functionally interact in a manner that is regulated by Goo activation (Ramaker et al., 2013). By co-expressing fusion constructs of APPL and G $\alpha$ o containing complementary portions of Venus fluorescent protein in transfected COS7 cells, bimolecular fluorescence complementation (BiFC) assays were used to demonstrate that

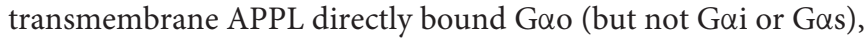
while $\mathrm{APP}_{695}$ also directly bound $\mathrm{G} \alpha 0$, similar to conventional GPCRs (Marinissen and Gutkind, 2001; Oldham and Hamm, 2008). More importantly, expressing these constructs in transgenic Drosophila lines revealed that APPL bound Goo in healthy neurons, providing the first demonstration of direct interactions between an APP family protein and Goo in vivo. Notably, this interaction could be readily visualized within synaptic regions of the brain by $\mathrm{BiFC}$, whereas deleting the Go domain in APPL (Figure $\mathbf{1 D}_{2}$ ) eliminated APPL-G $\alpha_{0}$ binding
(Ramaker et al., 2013). In combination, these studies substantiate the model that APP family proteins can indeed function as unconventional GPCRs, specifically regulating Goo-dependent responses.

By adapting an embryo culture assay that permits targeted manipulations of migratory neurons in Manduca (Horgan and Copenhaver, 1998), the Copenhaver laboratory subsequently showed that APPL-G $\alpha$ o signaling plays an important role in regulating neuronal motile behaviors: inhibiting either APPL expression or $\mathrm{G} \alpha \mathrm{o}$ activity induced a distinctive pattern of ectopic growth and migration, while hyperstimulating the APPL-G $\alpha 0$ pathway induced collapse-stall responses (Ramaker et al., 2013). These effects were analogous to the striking pattern of ectopic neuronal migration reported in the brains of mice deleted for all three APP family proteins (Herms et al., 2004), and recapitulated earlier studies in Manduca showing that activated Goo inhibits migration via the induction of voltage-independent currents 
(Horgan et al., 1995; Horgan and Copenhaver, 1998). More recent studies have identified Manduca Contactin (MsContactin) as a candidate ligand for APPL (Ramaker et al., 2016b). Specifically, experiments in cultured embryos indicated that GPI-linked MsContactin (expressed by adjacent glial cells) activates APPLG $\alpha$ o signaling in the migratory neurons to induce local retraction responses (Figure 2B), thereby preventing ectopic outgrowth. This discovery was supported by reports that multiple Contactin family members in mammalian systems can interact with APP and its orthologs both in cis and trans (Ma et al., 2008; Osterfield et al., 2008; Tachi et al., 2010; Osterhout et al., 2015). In summary, our experiments provide new evidence that APP family proteins regulate key aspects of neuronal development during embryogenesis, in part via activation of G $\alpha$ o-dependent pathways. Still to be determined are the downstream effectors that transduce the effects of APPL-G $\alpha$ o signaling on neuronal behavior. Likewise, whether mammalian Contactins might regulate APP-Goo signaling in migratory cortical neurons, and whether modulation of the PI3K-Akt pathway or GSK3 $\beta$ activity also contributes to this response within the developing nervous system remains to be explored (e.g., Morgan-Smith et al., 2014).

\section{APP MAY ALSO REGULATE NEURONAL MOTILITY via $G \alpha S$-DEPENDENT PATHWAYS}

Most studies support the model that transmembrane APP normally binds and activates $\mathrm{G} \alpha \mathrm{o}$ in response to a variety of ligands (including sAPP $\alpha$ and MsContactin), suggesting that APP cleavage (by secretases or caspases) is likely to terminate APPG $\alpha$ o signaling rather than activating it. In support of this model, we recently showed that blocking $\alpha$-secretase activity in the migratory neurons of cultured Manduca embryos significantly increased membrane-associated APPL levels, while inducing the same collapse/stall responses caused by hyperactivating APPLGao signaling with Contactin fusion proteins (Ramaker et al., 2016a,b). Likewise, our analysis of endogenously expressed APP family proteins showed that G $\alpha$ o could be readily coimmunoprecipitated with both full length $\mathrm{APP}_{695}$ (from mouse and human brain lysates) and APPL (from Manduca and Drosophila lysates), whereas we did not detect their CTF or AICD fragments in the immunoprecipitated complexes (Ramaker et al., 2013). These results are also consistent with past work focusing on the functional interactions between transmembrane $\mathrm{APP}_{695}$ and G $\alpha$ o (e.g., Okamoto et al., 1995; Hashimoto et al., 2003a; Sola Vigo et al., 2009). However, as noted above, several reports have shown that $\mathrm{G} \alpha$ o can also interact with membrane-tethered peptide 20 domains (mimicking CTFs that contain the Gobinding domain), and one study showed that $\mathrm{G} \alpha$ o could be coimmunoprecipitated with C99 fragments (normally generated by $\beta$-secretase cleavage) when overexpressed in neuroblastoma cells (Shaked et al., 2009). Whether Gao actually continues to interact with CTFs following $\alpha$ - or $\beta$-cleavage of the holoprotein in neurons, and whether these interactions might affect downstream pathways regulated by APP-G $\alpha$ o signaling under physiological conditions, is still unknown.
In contrast, recent studies by Parent and colleagues have indicated that a different $\mathrm{G}$ protein $(\mathrm{G} \alpha \mathrm{s})$ may be activated by CTFs derived from the APP holoprotein (Deyts et al., 2012). Specifically, they found that overexpressing a membranetethered AICD construct (mAICD) or experimentally elevating intracellular APP-CTF levels dramatically increased neurite outgrowth in both neuroblastoma cells and transfected cortical neurons. This response required AC-dependent activation of protein kinase $\mathrm{A}$ (PKA) and corresponded to the phosphorylation of two PKA targets (CREB and GSK3 $\beta$ ), both of which can regulate neuronal motility. To test the involvement of Gas (a canonical activator of AC), they also showed that HA-tagged Gas could be co-immunoprecipitated with mAICD from transfected cells, whereas dominant-negative Gas (lacking its palmitoylation site) prevented mAICD-induced outgrowth. Focusing on the BBXXB motif in APP that was originally identified by Nishimoto et al. (1993) (Figure 2C, asterisks), Deyts et al. (2012) found that mutating this site prevented interactions between the MAICD construct and HA-Gas. Curiously, they also demonstrated an interaction between $\mathrm{G} \alpha$ s and an equivalent construct derived from APLP1, which (like insect APPL) lacks a BBXXB motif (Figure 1C, boxed region), suggesting that this motif may not be strictly required for functional interactions between APP family proteins and $\mathrm{G} \alpha$ subunits within intact neurons.

More recently, the Parent group conducted a series of carefully controlled experiments in both cultured neurons and transgenic mice, demonstrating that elevating APP-CTF levels (by a variety of methods) induced exuberant neurite outgrowth, coincident with enhanced PKA and CREB phosphorylation (Deyts et al., 2016a). Consistent with their earlier work, they found that overexpressing $\beta$-CTF fragments of APP (C99) also stimulated outgrowth, whereas a C99 construct with a mutated BBXXB motif did not. Lastly, they showed that treatment with an AC inhibitor prevented increased outgrowth and phosphorylated CREB levels in their assays, again implicating Gas-dependent signaling. Whether Gas endogenously interacts with APP-CTFs in healthy neurons and whether this interaction is perturbed over the course of $\mathrm{AD}$ remains to be explored. Nevertheless, given available evidence that $G \alpha$ o normally interacts with full-length APP but not its fragments in neurons (as summarized above), these results support the intriguing view that APP cleavage might induce a novel type of $\mathrm{G}$ protein switching (Tucek et al., 2002; Woehler and Ponimaskin, 2009), whereby the holoprotein signals as a transmembrane receptor specifically via $G \alpha o$, while its CTF fragments can selectively regulate Gas-dependent pathways (Figure 2C). In the context of neuronal development, this model might also help explain how APP-dependent signaling can promote neuronal motility in some contexts while restricting it in others.

\section{CONCLUSION AND PERSPECTIVE: LIGAND-DEPENDENT MODULATION OF APP-G $\alpha O$ SIGNALING}

Despite considerable efforts to establish a role for aberrant APP$\mathrm{G} \alpha \mathrm{o}$ signaling in $\mathrm{AD}$, proof for this model has been hindered 
by incomplete understanding of the mechanisms that normally regulate this pathway in the brain. Because past studies often relied on rather artificial assays and overexpression systems, it is still unclear whether hyperstimulating this pathway results in the misregulation of endogenous signaling responses or produces novel gain-of-function effects that normally do not occur in the brain. Our laboratories have now approached this issue using complementary strategies, with the goal of understanding how this evolutionarily conserved signaling pathway regulates neuronal functions in both the developing and mature nervous system. As summarized in Figure 2A, sAPP $\alpha$ ectodomain fragments are clearly able to activate the PI3K/Akt pathway and modulate neuronal stress signaling, a response that undoubtedly plays important roles in both the developing and adult brain (Kögel et al., 2012; Milosch et al., 2014). By comparison, Contactin-dependent activation of APP-Go signaling can regulate the motile behavior of developing neurons (Figure 2B), in part by modulating $\mathrm{Ca}^{2+}$ influx and downstream effectors that modulate cytoskeletal dynamics (Horgan and Copenhaver, 1998; Copenhaver and Ramaker, 2016). Evidence that CTF fragments might also regulate neuronal behavior via Gas (Figure 2C) suggests that $G$ protein switching could also contribute to the refinement of APP-dependent motile responses (Deyts et al., 2012, 2016a).

We postulate that our different experimental preparations have revealed an important aspect of APP-Go signaling: namely, that the integration of this pathway with alternative or complementary effectors can be strongly influenced by particular combinations of ligands and co-receptors for APP that are expressed in a context-dependent manner. As has been reviewed elsewhere, APP family proteins can interact with a wide variety of candidate binding partners (Hoe et al., 2009; Jacobsen and Iverfeldt, 2009; Rice et al., 2013; Deyts et al., 2016b), although most of these interactions have yet to be validated in vivo. For example, experiments using cultured neurons have shown that stimulation with $\mathrm{APP} \alpha$ can promote APP-dependent outgrowth via interactions with members of the integrin and L1CAM families (Osterfield et al., 2008; YoungPearse et al., 2008), a response that can be further modulated by extracellular proteins like Reelin, F-spondin, and Semaphorin 3A (Ho and Sudhof, 2004; Hoe et al., 2009; Magdesian et al., 2011). More recently, elegant work by Young-Pearse and colleagues showed that different members of the pancortin family can both promote and inhibit APP-dependent responses in migrating cortical neurons, possibly via a combination of direct and indirect interactions (Rice et al., 2012). Whether these interactions also regulate Go-dependent aspects of motility remains to be explored. Outside the nervous system, APP family proteins are strongly upregulated by keratinocytes during wound healing (Herzog et al., 2004), while treatment with sAPP $\alpha$ stimulates their motile behavior (Kirfel et al., 2002), although it is unclear if this response is transduced by APP or other receptors. From a developmental perspective, ample precedent for this model of APP-Go signaling can be found in the responses elicited by other neuronal guidance receptors that can both stimulate and inhibit outgrowth, depending on a variety of interacting factors (Nishiyama et al., 2003; Egea and Klein, 2007; Yoshida, 2012; Finci et al., 2014; Kaplan et al., 2014). Likewise, whether activation of APP-Gao signaling induces neuroprotective or neurotoxic responses might be strongly affected by convergent input from physiological stimuli (particularly sAPP $\alpha$ ) or pathological factors (including $\mathrm{A} \beta_{42}$ oligomers).

Lastly, it should be noted that APP expression is significantly altered in a variety of other diseases besides $\mathrm{AD}$. In Down syndrome (DS), trisomy 21 results in a triplication of the gene encoding APP (as well as many other genes; Antonarakis et al., 2004), and most DS patients exhibit accelerated A $\beta$ accumulation and develop $\mathrm{AD}$-like neurological pathologies (Millan Sanchez et al., 2012; Castro et al., 2016). APP expression is also dramatically upregulated in the brain following traumatic brain injury (Plummer et al., 2016; Acosta et al., 2017) and in lesions associated with epilepsy and multiple sclerosis (Noebels, 2011; Matias-Guiu et al., 2016). Whether APP serves a neuroprotective function or promotes degenerative responses in these diseases is still unknown; hence, determining how APP-G $\alpha$ o signaling is altered in $\mathrm{AD}$ should also be relevant to other conditions in which this pathway might be misregulated. Only by fully defining the normal mechanisms of APP-Go signaling in the brain will it be possible to resolve how the misregulation of this pathway may contribute to the pathological sequelae that give rise to $\mathrm{AD}$.

\section{AUTHOR CONTRIBUTIONS}

PC and DK contributed equally to all aspects of this review, including development of the overall concept, writing and correcting the text, and creating the table and figures included in the review.

\section{FUNDING}

Work from the Copenhaver laboratory was funded in part by NIH grants NS078363 and AG025525 to PC, who also received support from OHSU Presidential Bridge Funding Award. Work from the Kögel lab was funded by the Deutsche Forschungsgemeinschaft (DFG, grants KO 1898/6-1 and 10/1). The authors declare no competing financial interests.

\section{ACKNOWLEDGMENT}

We thank Dr. Doris Kretzschmar for critical input on this review. 


\section{REFERENCES}

Abe, Y., Hashimoto, Y., Tomita, Y., Terashita, K., Aiso, S., Tajima, H., et al. (2004). Cytotoxic mechanisms by M239V presenilin 2, a little-analyzed Alzheimer's disease-causative mutant. J. Neurosci. Res. 77, 583-595. doi: 10.1002/jnr.20163

Acosta, S. A., Tajiri, N., Sanberg, P. R., Kaneko, Y., and Borlongan, C. V. (2017). Increased amyloid precursor protein and tau expression manifests as key secondary cell death in chronic traumatic brain injury. J. Cell. Physiol. 232, 665-677. doi: 10.1002/jcp.25629

Adlerz, L., Holback, S., Multhaup, G., and Iverfeldt, K. (2007). IGF-1-induced processing of the amyloid precursor protein family is mediated by different signaling pathways. J. Biol. Chem. 282, 10203-10209. doi: 10.1074/jbc. M611183200

Almkvist, O., Basun, H., Wagner, S. L., Rowe, B. A., Wahlund, L. O., and Lannfelt, L. (1997). Cerebrospinal fluid levels of alpha-secretase-cleaved soluble amyloid precursor protein mirror cognition in a Swedish family with Alzheimer disease and a gene mutation. Arch. Neurol. 54, 641-644. doi: 10.1001/archneur. 1997.00550170111022

Antonarakis, S. E., Lyle, R., Dermitzakis, E. T., Reymond, A., and Deutsch, S. (2004). Chromosome 21 and down syndrome: from genomics to pathophysiology. Nat. Rev. Genet. 5, 725-738. doi: 10.1038/nrg1448

Ayala, R., Shu, T., and Tsai, L. H. (2007). Trekking across the brain: the journey of neuronal migration. Cell 128, 29-43. doi: 10.1016/j.cell.2006.12.021

Bourdet, I., Preat, T., and Goguel, V. (2015). The full-length form of the Drosophila amyloid precursor protein is involved in memory formation. J. Neurosci. 35, 1043-1051. doi: 10.1523/JNEUROSCI.2093-14.2015

Bromberg, K. D., Iyengar, R., and He, J. C. (2008). Regulation of neurite outgrowth by G(i/o) signaling pathways. Front. Biosci. 13:4544-4557. doi: 10.2741/3022

Brouillet, E., Trembleau, A., Galanaud, D., Volovitch, M., Bouillot, C., Valenza, C., et al. (1999). The amyloid precursor protein interacts with Go heterotrimeric protein within a cell compartment specialized in signal transduction. J. Neurosci. 19, 1717-1727.

Cassar, M., and Kretzschmar, D. (2016). Analysis of amyloid precursor protein function in Drosophila melanogaster. Front. Mol. Neurosci. 9:61. doi: 10.3389/ fnmol.2016.00061

Castro, P., Zaman, S., and Holland, A. (2016). Alzheimer's disease in people with down's syndrome: the prospects for and the challenges of developing preventative treatments. J. Neurol. doi: 10.1007/s00415-016-8308-8 [Epub ahead of print].

Cheng, G., Yu, Z., Zhou, D., and Mattson, M. P. (2002). Phosphatidylinositol3-kinase-Akt kinase and p42/p44 mitogen-activated protein kinases mediate neurotrophic and excitoprotective actions of a secreted form of amyloid precursor protein. Exp. Neurol. 175, 407-414. doi: 10.1006/exnr.2002.7920

Colombo, M. I., Mayorga, L. S., Nishimoto, I., Ross, E. M., and Stahl, P. D. (1994). Gs regulation of endosome fusion suggests a role for signal transduction pathways in endocytosis. J. Biol. Chem. 269, 14919-14923.

Copanaki, E., Chang, S., Vlachos, A., Tschape, J. A., Muller, U. C., Vogel, D., et al. (2010). sAPPalpha antagonizes dendritic degeneration and neuron death triggered by proteasomal stress. Mol. Cell. Neurosci. 44, 386-393. doi: 10.1016/ j.mcn.2010.04.007

Copenhaver, P. F. (2007). How to innervate a simple gut: familiar themes and unique aspects in the formation of the insect enteric nervous system. Dev. Dyn. 236, 1841-1864. doi: $10.1002 /$ dvdy.21138

Copenhaver, P. F., and Ramaker, J. M. (2016). Neuronal migration during development and the amyloid precursor protein. Curr. Opin. Insect Sci. 18, 1-10. doi: 10.1016/j.cois.2016.08.001

Copenhaver, P. F., and Taghert, P. H. (1989). Development of the enteric nervous system in the moth. II. Stereotyped cell migration precedes the differentiation of embryonic neurons. Dev. Biol. 131, 85-101. doi: 10.1016/S0012-1606(89) 80040-5

Coulson, E. J., Paliga, K., Beyreuther, K., and Masters, C. L. (2000). What the evolution of the amyloid protein precursor supergene family tells us about its function. Neurochem. Int. 36, 175-184. doi: 10.1016/S0197-0186(99)00125-4

Cowburn, R. F., O’Neill, C., Bonkale, W. L., Ohm, T. G., and Fastbom, J. (2001). Receptor-G-protein signalling in Alzheimer's disease. Biochem. Soc. Symp. 67, 163-175. doi: 10.1042/bss0670163

Crews, L., and Masliah, E. (2010). Molecular mechanisms of neurodegeneration in Alzheimer's disease. Hum. Mol. Genet. 19, R12-R20. doi: 10.1093/hmg/ddq160
Datta, S. R., Dudek, H., Tao, X., Masters, S., Fu, H., Gotoh, Y., et al. (1997). Akt phosphorylation of BAD couples survival signals to the cell-intrinsic death machinery. Cell 91, 231-241. doi: 10.1016/S0092-8674(00)80405-5

Deng, J., Habib, A., Obregon, D. F., Barger, S. W., Giunta, B., Wang, Y. J., et al. (2015). Soluble amyloid precursor protein alpha inhibits tau phosphorylation through modulation of GSK3beta signaling pathway. J. Neurochem. 135, 630637. doi: 10.1111/jnc. 13351

Deyts, C., Clutter, M., Herrera, S., Jovanovic, N., Goddi, A., and Parent, A. T. (2016a). Loss of presenilin function is associated with a selective gain of APP function. eLife 5, 1-24. doi: 10.7554/eLife.15645

Deyts, C., Thinakaran, G., and Parent, A. T. (2016b). APP receptor? To be or not to be. Trends Pharmacol. Sci. 37, 390-411. doi: 10.1016/j.tips.2016. 01.005

Deyts, C., Vetrivel, K. S., Das, S., Shepherd, Y. M., Dupre, D. J., Thinakaran, G., et al. (2012). Novel GalphaS-protein signaling associated with membrane-tethered amyloid precursor protein intracellular domain. J. Neurosci. 32, 1714-1729. doi: 10.1523/JNEUROSCI.5433-11.2012

Eckert, G. P., Chang, S., Eckmann, J., Copanaki, E., Hagl, S., Hener, U., et al. (2011). Liposome-incorporated DHA increases neuronal survival by enhancing non-amyloidogenic APP processing. Biochim. Biophys. Acta 1808, 236-243. doi: 10.1016/j.bbamem.2010.10.014

Egea, J., and Klein, R. (2007). Bidirectional Eph-ephrin signaling during axon guidance. Trends Cell Biol. 17, 230-238. doi: 10.1016/j.tcb.2007.03.004

Endo, H., Nito, C., Kamada, H., Nishi, T., and Chan, P. H. (2006). Activation of the Akt/GSK3beta signaling pathway mediates survival of vulnerable hippocampal neurons after transient global cerebral ischemia in rats. J. Cereb. Blood Flow Metab. 26, 1479-1489. doi: 10.1038/si.jcbfm.9600303

Ewald, C. Y., and Li, C. (2012). The secreted Alzheimer-related amyloid precursor protein fragment has an essential role in C. elegans. Prion 6, 433-436. doi: $10.4161 /$ pri.22310

Ewald, C. Y., Marfil, V., and Li, C. (2016). Alzheimer-related protein APL-1 modulates lifespan through heterochronic gene regulation in Caenorhabditis elegans. Aging Cell doi: 10.1111/acel.12509 [Epub ahead of print].

Finci, L. I., Kruger, N., Sun, X., Zhang, J., Chegkazi, M., Wu, Y., et al. (2014). The crystal structure of netrin-1 in complex with DCC reveals the bifunctionality of netrin-1 as a guidance cue. Neuron 83, 839-849. doi: 10.1016/j.neuron.2014. 07.010

Fogel, H., Frere, S., Segev, O., Bharill, S., Shapira, I., Gazit, N., et al. (2014). APP homodimers transduce an amyloid-beta-mediated increase in release probability at excitatory synapses. Cell Rep. 7, 1560-1576. doi: 10.1016/j.celrep. 2014.04.024

Galvan, V., Gorostiza, O. F., Banwait, S., Ataie, M., Logvinova, A. V., Sitaraman, S., et al. (2007). Reversal of Alzheimer's-like pathology and behavior in human APP transgenic mice by mutation of Asp664. Proc. Natl. Acad. Sci. U.S.A. 104:6876. doi: 10.1073/pnas.0509695103

Garcia-Jimenez, A., Cowburn, R. F., Ohm, T. G., Lasn, H., Winblad, B., Bogdanovic, N., et al. (2002). Loss of stimulatory effect of guanosine triphosphate on [(35)S]GTPgammaS binding correlates with Alzheimer's disease neurofibrillary pathology in entorhinal cortex and CA1 hippocampal subfield. J. Neurosci. Res. 67, 388-398. doi: 10.1002/jnr.10125

Giambarella, U., Murayama, Y., Ikezu, T., Fujita, T., and Nishimoto, I. (1997). Potential CRE suppression by familial Alzheimer's mutants of APP independent of adenylyl cyclase regulation. FEBS Lett. 412, 97-101. doi: 10.1016/S00145793(97)00753-9

Goldsmith, Z. G., and Dhanasekaran, D. N. (2007). G protein regulation of MAPK networks. Oncogene 26, 3122-3142. doi: 10.1038/sj.onc.1210407

Gralle, M., Botelho, M. G., and Wouters, F. S. (2009). Neuroprotective secreted amyloid precursor protein acts by disrupting amyloid precursor protein dimers. J. Biol. Chem. 284, 15016-15025. doi: 10.1074/jbc.M808755200

Hamm, H. E., Deretic, D., Arendt, A., Hargrave, P. A., Koenig, B., and Hofmann, K. P. (1988). Site of G protein binding to rhodopsin mapped with synthetic peptides from the alpha subunit. Science 241, 832-835. doi: 10.1126/science. 3136547

Hanumanthappa, P., Densi, A., and Krishnamurthy, R. G. (2014). Glycogen synthase kinase-beta3 in ischemic neuronal death. Curr. Neurovasc. Res. 11 271-278. doi: 10.2174/1567202611666140520151002

Hashimoto, Y., Niikura, T., Chiba, T., Tsukamoto, E., Kadowaki, H., Nishitoh, H., et al. (2003a). The cytoplasmic domain of Alzheimer's amyloid-beta protein 
precursor causes sustained apoptosis signal-regulating kinase 1/c-Jun NH2terminal kinase-mediated neurotoxic signal via dimerization. J. Pharmacol. Exp. Ther. 306, 889-902. doi: 10.1124/jpet.103.051383

Hashimoto, Y., Niikura, T., Ito, Y., and Nishimoto, I. (2000). Multiple mechanisms underlie neurotoxicity by different types of Alzheimer's disease mutations of amyloid precursor protein. J. Biol. Chem. 275, 34541-34551. doi: 10.1074/jbc. M005332200

Hashimoto, Y., Tsuji, O., Niikura, T., Yamagishi, Y., Ishizaka, M., Kawasumi, M., et al. (2003b). Involvement of c-Jun N-terminal kinase in amyloid precursor protein-mediated neuronal cell death. J. Neurochem. 84, 864-877. doi: 10.1046/ j.1471-4159.2003.01585.x

Hawkes, C., Amritraj, A., Macdonald, R. G., Jhamandas, J. H., and Kar, S. (2007). Heterotrimeric $\mathrm{G}$ proteins and the single-transmembrane domain IGF-II/M6P receptor: functional interaction and relevance to cell signaling. Mol. Neurobiol. 35, 329-345. doi: 10.1007/s12035-007-0021-2

Heldin, C. H., Lu, B., Evans, R., and Gutkind, J. S. (2016). Signals and receptors. Cold Spring Harb. Perspect. Biol 8:a005900. doi: 10.1101/cshperspect.a005900

Herms, J., Anliker, B., Heber, S., Ring, S., Fuhrmann, M., Kretzschmar, H., et al. (2004). Cortical dysplasia resembling human type 2 lissencephaly in mice lacking all three APP family members. EMBO J. 23, 4106-4115. doi: 10.1038/ sj.emboj.7600390

Herrmann, R., Heck, M., Henklein, P., Henklein, P., Kleuss, C., Hofmann, K. P., et al. (2004). Sequence of interactions in receptor-G protein coupling. J. Biol. Chem. 279, 24283-24290. doi: 10.1074/jbc.M311166200

Herzog, V., Kirfel, G., Siemes, C., and Schmitz, A. (2004). Biological roles of APP in the epidermis. Eur. J. Cell Biol. 83, 613-624. doi: 10.1078/0171-9335-00401

Ho, A., and Sudhof, T. C. (2004). Binding of F-spondin to amyloid-beta precursor protein: a candidate amyloid-beta precursor protein ligand that modulates amyloid-beta precursor protein cleavage. Proc. Natl. Acad. Sci. U.S.A. 101, 2548-2553. doi: 10.1073/pnas.0308655100

Hoe, H. S., Lee, K. J., Carney, R. S., Lee, J., Markova, A., Lee, J. Y., et al. (2009). Interaction of reelin with amyloid precursor protein promotes neurite outgrowth. J. Neurosci. 29, 7459-7473. doi: 10.1523/JNEUROSCI.4872-08.2009

Horgan, A. M., and Copenhaver, P. F. (1998). G protein-mediated inhibition of neuronal migration requires calcium influx. J. Neurosci. 18, 4189-4200.

Horgan, A. M., Lagrange, M. T., and Copenhaver, P. F. (1995). A developmental role for the heterotrimeric $\mathrm{G}$ protein Go alpha in a migratory population of embryonic neurons. Dev. Biol. 172, 640-653. doi: 10.1006/dbio.1995.8042

Hornsten, A., Lieberthal, J., Fadia, S., Malins, R., Ha, L., Xu, X., et al. (2007). APL-1, a Caenorhabditis elegans protein related to the human beta-amyloid precursor protein, is essential for viability. Proc. Natl. Acad. Sci. U.S.A. 104, 1971-1976. doi: $10.1073 /$ pnas.0603997104

Ikezu, T., Okamoto, T., Komatsuzaki, K., Matsui, T., Martyn, J. A., and Nishimoto, I. (1996). Negative transactivation of cAMP response element by familial Alzheimer's mutants of APP. EMBO J. 15, 2468-2475.

Jacobsen, K. T., and Iverfeldt, K. (2009). Amyloid precursor protein and its homologues: a family of proteolysis-dependent receptors. Cell Mol. Life. Sci. 66, 2299-2318. doi: 10.1007/s00018-009-0020-8

Jayne, T., Newman, M., Verdile, G., Sutherland, G., Munch, G., Musgrave, I., et al. (2016). Evidence for and against a pathogenic role of reduced gammasecretase activity in familial Alzheimer's disease. J. Alzheimers Dis. 52, 781-799. doi: 10.3233/JAD- 151186

Jiang, M., and Bajpayee, N. S. (2009). Molecular mechanisms of Go signaling. Neurosignals 17, 23-41. doi: 10.1159/000186688

Jimenez, S., Torres, M., Vizuete, M., Sanchez-Varo, R., Sanchez-Mejias, E., TrujilloEstrada, L., et al. (2011). Age-dependent accumulation of soluble amyloid beta (Abeta) oligomers reverses the neuroprotective effect of soluble amyloid precursor protein-alpha (sAPP(alpha)) by modulating phosphatidylinositol 3kinase (PI3K)/Akt-GSK-3beta pathway in Alzheimer mouse model. J. Biol. Chem. 286, 18414-18425. doi: 10.1074/jbc.M110.209718

Jover-Mengual, T., Miyawaki, T., Latuszek, A., Alborch, E., Zukin, R. S., and Etgen, A. M. (2010). Acute estradiol protects CA1 neurons from ischemiainduced apoptotic cell death via the PI3K/Akt pathway. Brain Res. 1321, 1-12. doi: 10.1016/j.brainres.2010.01.046

Kaden, D., Munter, L. M., Reif, B., and Multhaup, G. (2012). The amyloid precursor protein and its homologues: structural and functional aspects of native and pathogenic oligomerization. Eur. J. Cell Biol. 91, 234-239. doi: 10.1016/j.ejcb. 2011.01.017
Kaplan, A., Kent, C. B., Charron, F., and Fournier, A. E. (2014). Switching responses: spatial and temporal regulators of axon guidance. Mol. Neurobiol. 49, 1077-1086. doi: 10.1007/s12035-013-8582-8

Karelson, E., Fernaeus, S., Reis, K., Bogdanovic, N., and Land, T. (2005). Stimulation of G-proteins in human control and Alzheimer's disease brain by FAD mutants of APP(714-723): implication of oxidative mechanisms. J. Neurosci. Res. 79, 368-374. doi: 10.1002/jnr.20371

Kawasumi, M., Matsuda, S., Matsuoka, M., and Nishimoto, I. (2004). Cytoplasmic tail adaptors of Alzheimer's amyloid-beta protein precursor. Mol. Neurobiol. 30, 185-200. doi: 10.1385/MN:30:2:185

King, G. D., and Scott Turner, R. (2004). Adaptor protein interactions: modulators of amyloid precursor protein metabolism and Alzheimer's disease risk? Exp. Neurol. 185, 208-219. doi: 10.1016/j.expneurol.2003.10.011

Kirfel, G., Borm, B., Rigort, A., and Herzog, V. (2002). The secretory beta-amyloid precursor protein is a motogen for human epidermal keratinocytes. Eur. J. Cell Biol. 81, 664-676. doi: 10.1078/0171-9335-00284

Kögel, D., Deller, T., and Behl, C. (2012). Roles of amyloid precursor protein family members in neuroprotection, stress signaling and aging. Exp. Brain Res. 217, 471-479. doi: 10.1007/s00221-011-2932-4

Kögel, D., Schomburg, R., Copanaki, E., and Prehn, J. H. (2005). Regulation of gene expression by the amyloid precursor protein: inhibition of the JNK/c-Jun pathway. Cell Death Differ. 12, 1-9. doi: 10.1038/sj.cdd.4401495

Kögel, D., Schomburg, R., Schurmann, T., Reimertz, C., Konig, H. G., Poppe, M., et al. (2003). The amyloid precursor protein protects PC12 cells against endoplasmic reticulum stress-induced apoptosis. J. Neurochem. 87, 248-256. doi: 10.1046/j.1471-4159.2003.02000.x

Lai, A., Sisodia, S. S., and Trowbridge, I. S. (1995). Characterization of sorting signals in the beta-amyloid precursor protein cytoplasmic domain. J. Biol. Chem. 270, 3565-3573. doi: 10.1074/jbc.270.8.3565

Lang, J., Nishimoto, I., Okamoto, T., Regazzi, R., Kiraly, C., Weller, U., et al. (1995). Direct control of exocytosis by receptor-mediated activation of the heterotrimeric GTPases Gi and G(o) or by the expression of their active G alpha subunits. EMBO J. 14, 3635-3644.

Lazarov, O., and Demars, M. P. (2012). All in the family: how the APPs regulate neurogenesis. Front. Neurosci. 6:81. doi: 10.3389/fnins.2012.00081

Llorens-Martin, M., Jurado, J., Hernandez, F., and Avila, J. (2014). GSK-3beta, a pivotal kinase in Alzheimer disease. Front. Mol. Neurosci. 7:46. doi: 10.3389/ fnmol.2014.00046

Lorenzo, A., Yuan, M., Zhang, Z., Paganetti, P. A., Sturchler-Pierrat, C., Staufenbiel, M., et al. (2000). Amyloid beta interacts with the amyloid precursor protein: a potential toxic mechanism in Alzheimer's disease. Nat. Neurosci. 3, 460-464. doi: 10.1038/74833

Lu, D. C., Soriano, S., Bredesen, D. E., and Koo, E. H. (2003). Caspase cleavage of the amyloid precursor protein modulates amyloid beta-protein toxicity. J. Neurochem. 87, 733-741. doi: 10.1046/j.1471-4159.2003.02059.x

Ma, Q. H., Futagawa, T., Yang, W. L., Jiang, X. D., Zeng, L., Takeda, Y., et al. (2008). A TAG1-APP signalling pathway through Fe65 negatively modulates neurogenesis. Nat. Cell Biol. 10, 283-294. doi: 10.1038/ncb1690

Magdesian, M. H., Gralle, M., Guerreiro, L. H., Beltrao, P. J., Carvalho, M. M., Santos, L. E., et al. (2011). Secreted human amyloid precursor protein binds semaphorin $3 \mathrm{a}$ and prevents semaphorin-induced growth cone collapse. PLoS ONE 6:e22857. doi: 10.1371/journal.pone.0022857

Mahlapuu, R., Viht, K., Balaspiri, L., Bogdanovic, N., Saar, K., Soomets, U., et al. (2003). Amyloid precursor protein carboxy-terminal fragments modulate G-proteins and adenylate cyclase activity in Alzheimer's disease brain. Brain Res. Mol. Brain Res. 117, 73-82. doi: 10.1016/S0169-328X(03) 00292-4

Marinissen, M. J., and Gutkind, J. S. (2001). G-protein-coupled receptors and signaling networks: emerging paradigms. Trends Pharmacol. Sci. 22, 368-376. doi: 10.1016/S0165-6147(00)01678-3

Matias-Guiu, J. A., Oreja-Guevara, C., Cabrera-Martin, M. N., Moreno-Ramos, T., Carreras, J. L., and Matias-Guiu, J. (2016). Amyloid proteins and their role in multiple sclerosis. considerations in the use of amyloid-PET imaging. Front. Neurol. 7:53. doi: 10.3389/fneur.2016.00053

Mattson, M. P., Cheng, B., Culwell, A. R., Esch, F. S., Lieberburg, I., and Rydel, R. E. (1993). Evidence for excitoprotective and intraneuronal calcium-regulating roles for secreted forms of the beta-amyloid precursor protein. Neuron 10 , 243-254. doi: 10.1016/0896-6273(93)90315-I 
Mbebi, C., See, V., Mercken, L., Pradier, L., Muller, U., and Loeffler, J. P. (2002). Amyloid precursor protein family-induced neuronal death is mediated by impairment of the neuroprotective calcium/calmodulin protein kinase IVdependent signaling pathway. J. Biol. Chem. 277, 20979-20990. doi: 10.1074/ jbc.M107948200

McPhie, D. L., Coopersmith, R., Hines-Peralta, A., Chen, Y., Ivins, K. J., Manly, S. P., et al. (2003). DNA synthesis and neuronal apoptosis caused by familial Alzheimer disease mutants of the amyloid precursor protein are mediated by the p21 activated kinase PAK3. J. Neurosci. 23, 6914-6927.

Millan Sanchez, M., Heyn, S. N., Das, D., Moghadam, S., Martin, K. J., and Salehi, A. (2012). Neurobiological elements of cognitive dysfunction in down syndrome: exploring the role of APP. Biol. Psychiatry 71, 403-409. doi: 10.1016/j.biopsych. 2011.08.016

Milosch, N., Tanriover, G., Kundu, A., Rami, A., Francois, J. C., Baumkotter, F., et al. (2014). Holo-APP and G-protein-mediated signaling are required for sAPPalpha-induced activation of the Akt survival pathway. Cell Death Dis. 5:e1391. doi: 10.1038/cddis.2014.352

Morgan-Smith, M., Wu, Y., Zhu, X., Pringle, J., and Snider, W. D. (2014). GSK3 signaling in developing cortical neurons is essential for radial migration and dendritic orientation. eLife 3:e02663. doi: 10.7554/eLife.02663

Murga, C., Fukuhara, S., and Gutkind, J. S. (2000). A novel role for phosphatidylinositol 3-kinase beta in signaling from G protein-coupled receptors to Akt. J. Biol. Chem. 275, 12069-12073. doi: 10.1074/jbc.275.16.12069

Murga, C., Laguinge, L., Wetzker, R., Cuadrado, A., and Gutkind, J. S. (1998). Activation of Akt/protein kinase B by $\mathrm{G}$ protein-coupled receptors. A role for alpha and beta gamma subunits of heterotrimeric $\mathrm{G}$ proteins acting through phosphatidylinositol-3-OH kinasegamma. J. Biol. Chem. 273, 19080-19085. doi: $10.1074 /$ jbc.273.30.19080

New, D. C., and Wong, Y. H. (2007). Molecular mechanisms mediating the G protein-coupled receptor regulation of cell cycle progression. J. Mol. Signal. 2:2. doi: 10.1186/1750-2187-2-2

Nhan, H. S., Chiang, K., and Koo, E. H. (2015). The multifaceted nature of amyloid precursor protein and its proteolytic fragments: friends and foes. Acta Neuropathol. 129, 1-19. doi: 10.1007/s00401-014-1347-2

Niikura, T., Murayama, N., Hashimoto, Y., Ito, Y., Yamagishi, Y., Matsuoka, M., et al. (2000). V642I APP-inducible neuronal cells: a model system for investigating Alzheimer's disorders. Biochem. Biophys. Res. Commun. 274, 445454. doi: 10.1006/bbrc.2000.3143

Niikura, T., Yamada, M., Chiba, T., Aiso, S., Matsuoka, M., and Nishimoto, I. (2004). Characterization of V642I-AbetaPP-induced cytotoxicity in primary neurons. J. Neurosci. Res. 77, 54-62. doi: 10.1002/jnr.20139

Nishimoto, I., Okamoto, T., Matsuura, Y., Takahashi, S., Okamoto, T., Murayama, Y., et al. (1993). Alzheimer amyloid protein precursor complexes with brain GTP-binding protein G(o). Nature 362, 75-79. doi: 10.1038/ $362075 \mathrm{a} 0$

Nishiyama, M., Hoshino, A., Tsai, L., Henley, J. R., Goshima, Y., TessierLavigne, M., et al. (2003). Cyclic AMP/GMP-dependent modulation of $\mathrm{Ca}^{2+}$ channels sets the polarity of nerve growth-cone turning. Nature 424, 990-995. doi: 10.1038/nature01751

Noebels, J. (2011). A perfect storm: Converging paths of epilepsy and Alzheimer's dementia intersect in the hippocampal formation. Epilepsia 52(Suppl. 1), 39-46. doi: 10.1111/j.1528-1167.2010.02909.x

Okamoto, T., Katada, T., Murayama, Y., Ui, M., Ogata, E., and Nishimoto, I. (1990). A simple structure encodes G protein-activating function of the IGF-II/mannose 6-phosphate receptor. Cell 62, 709-717. doi: 10.1016/00928674(90)90116-V

Okamoto, T., Murayama, Y., Hayashi, Y., Inagaki, M., Ogata, E., and Nishimoto, I. (1991). Identification of a Gs activator region of the beta 2-adrenergic receptor that is autoregulated via protein kinase A-dependent phosphorylation. Cell 67, 723-730. doi: 10.1016/0092-8674(91)90067-9

Okamoto, T., and Nishimoto, I. (1992). Detection of G protein-activator regions in M4 subtype muscarinic, cholinergic, and alpha 2-adrenergic receptors based upon characteristics in primary structure. J. Biol. Chem. 267, 8342-8346.

Okamoto, T., Takeda, S., Giambarella, U., Murayama, Y., Matsui, T., Katada, T., et al. (1996). Intrinsic signaling function of APP as a novel target of three V642 mutations linked to familial Alzheimer's disease. EMBO J. 15, 3769-3777.
Okamoto, T., Takeda, S., Murayama, Y., Ogata, E., and Nishimoto, I. (1995). Ligand-dependent $\mathrm{G}$ protein coupling function of amyloid transmembrane precursor. J. Biol. Chem. 270, 4205-4208. doi: 10.1074/jbc.270.9.4205

Oldham, W. M., and Hamm, H. E. (2008). Heterotrimeric G protein activation by G-protein-coupled receptors. Nat. Rev. Mol. Cell Biol. 9, 60-71. doi: 10.1038/ nrm2299

O’Neill, C., Wiehager, B., Fowler, C. J., Ravid, R., Winblad, B., and Cowburn, R. F. (1994). Regionally selective alterations in G protein subunit levels in the Alzheimer's disease brain. Brain Res. 636, 193-201. doi: 10.1016/0006-8993(94) 91017-0

Osterfield, M., Egelund, R., Young, L. M., and Flanagan, J. G. (2008). Interaction of amyloid precursor protein with contactins and NgCAM in the retinotectal system. Development 135, 1189-1199. doi: 10.1242/dev.007401

Osterhout, J. A., Stafford, B. K., Nguyen, P. L., Yoshihara, Y., and Huberman, A. D. (2015). Contactin-4 mediates axon-target specificity and functional development of the accessory optic system. Neuron 86, 985-999. doi: 10.1016/j. neuron.2015.04.005

Patel, T. B. (2004). Single transmembrane spanning heterotrimeric g proteincoupled receptors and their signaling cascades. Pharmacol. Rev. 56, 371-385. doi: $10.1124 /$ pr.56.3.4

Plummer, S., Van den Heuvel, C., Thornton, E., Corrigan, F., and Cappai, R. (2016). The neuroprotective properties of the amyloid precursor protein following traumatic brain injury. Aging Dis. 7, 163-179. doi: 10.14336/AD.2015.0907

Ramaker, J. M., Cargill, R. S., Swanson, T. L., Quirindongo, H., Cassar, M., Kretzschmar, D., et al. (2016a). Amyloid precursor proteins are dynamically trafficked and processed during neuronal development. Front. Mol. Neurosci. 9:130. doi: 10.3389/fnmol.2016.00130

Ramaker, J. M., Swanson, T. L., and Copenhaver, P. F. (2013). Amyloid precursor proteins interact with the heterotrimeric $G$ protein Go in the control of neuronal migration. J. Neurosci. 33, 10165-10181. doi: 10.1523/JNEUROSCI. 1146-13.2013

Ramaker, J. M., Swanson, T. L., and Copenhaver, P. F. (2016b). Manduca contactin regulates amyloid precursor protein-dependent neuronal migration. J. Neurosci. 36, 8757-8775. doi: 10.1523/JNEUROSCI.0729-16.2016

Reis, K., Zharkovsky, A., Bogdanovic, N., Karelson, E., and Land, T. (2007). Critical role of methionine-722 in the stimulation of human brain G-proteins and neurotoxicity induced by London familial Alzheimer's disease (FAD) mutated V717G-APP(714-723). Neuroscience 144, 571-578. doi: 10.1016/j.neuroscience. 2006.10.007

Rice, H. C., Townsend, M., Bai, J., Suth, S., Cavanaugh, W., Selkoe, D. J., et al. (2012). Pancortins interact with amyloid precursor protein and modulate cortical cell migration. Development 139, 3986-3996. doi: 10.1242/dev.082909

Rice, H. C., Young-Pearse, T. L., and Selkoe, D. J. (2013). Systematic evaluation of candidate ligands regulating ectodomain shedding of amyloid precursor protein. Biochemistry 52, 3264-3277. doi: 10.1021/bi400165f

Ring, S., Weyer, S. W., Kilian, S. B., Waldron, E., Pietrzik, C. U., Filippov, M. A., et al. (2007). The secreted beta-amyloid precursor protein ectodomain APPs alpha is sufficient to rescue the anatomical, behavioral, and electrophysiological abnormalities of APP-deficient mice. J. Neurosci. 27, 7817-7826. doi: 10.1523/ JNEUROSCI.1026-07.2007

Rohn, T. T., Ivins, K. J., Bahr, B. A., Cotman, C. W., and Cribbs, D. H. (2000). A monoclonal antibody to amyloid precursor protein induces neuronal apoptosis. J. Neurochem. 74, 2331-2342. doi: 10.1046/j.1471-4159. 2000.0742331.x

Rymer, D. L., and Good, T. A. (2001). The role of G protein activation in the toxicity of amyloidogenic Abeta-(1-40), Abeta-(25-35), and bovine calcitonin. J. Biol. Chem. 276, 2523-2530. doi: 10.1074/jbc.M005800200

Scheuermann, S., Hambsch, B., Hesse, L., Stumm, J., Schmidt, C., Beher, D., et al. (2001). Homodimerization of amyloid precursor protein and its implication in the amyloidogenic pathway of Alzheimer's disease. J. Biol. Chem. 276, 33923-33929. doi: 10.1074/jbc.M105410200

Schubert, D., and Behl, C. (1993). The expression of amyloid beta protein precursor protects nerve cells from beta-amyloid and glutamate toxicity and alters their interaction with the extracellular matrix. Brain Res. 629, 275-282. doi: 10.1016/ 0006-8993(93)91331-L

Sennvik, K., Fastbom, J., Blomberg, M., Wahlund, L. O., Winblad, B., and Benedikz, E. (2000). Levels of alpha- and beta-secretase cleaved amyloid 
precursor protein in the cerebrospinal fluid of Alzheimer's disease patients. Neurosci. Lett. 278, 169-172. doi: 10.1016/S0304-3940(99)00929-5

Shaked, G. M., Chauv, S., Ubhi, K., Hansen, L. A., and Masliah, E. (2009). Interactions between the amyloid precursor protein $\mathrm{C}$-terminal domain and $\mathrm{G}$ proteins mediate calcium dysregulation and amyloid beta toxicity in Alzheimer's disease. FEBS J. 276, 2736-2751. doi: 10.1111/j.1742-4658.2009. 06997.x

Shariati, S. A., and De Strooper, B. (2013). Redundancy and divergence in the amyloid precursor protein family. FEBS Lett. 587, 2036-2045. doi: 10.1016/j. febslet.2013.05.026

Slunt, H. H., Thinakaran, G., Von Koch, C., Lo, A. C., Tanzi, R. E., and Sisodia, S. S. (1994). Expression of a ubiquitous, cross-reactive homologue of the mouse beta-amyloid precursor protein (APP). J. Biol. Chem. 269, 2637-2644.

Smine, A., Xu, X., Nishiyama, K., Katada, T., Gambetti, P., Yadav, S. P., et al. (1998). Regulation of brain G-protein go by Alzheimer's disease gene presenilin-1. J. Biol. Chem. 273, 16281-16288. doi: 10.1074/jbc.273.26.16281

Soba, P., Eggert, S., Wagner, K., Zentgraf, H., Siehl, K., Kreger, S., et al. (2005). Homo- and heterodimerization of APP family members promotes intercellular adhesion. EMBO J. 24, 3624-3634. doi: 10.1038/sj.emboj.7600824

Sola Vigo, F., Kedikian, G., Heredia, L., Heredia, F., Anel, A. D., Rosa, A. L., et al. (2009). Amyloid-beta precursor protein mediates neuronal toxicity of amyloid beta through Go protein activation. Neurobiol. Aging 30, 1379-1392. doi: 10.1016/j.neurobiolaging.2007.11.017

Strittmatter, S. M., Valenzuela, D., Kennedy, T. E., Neer, E. J., and Fishman, M. C. (1990). G0 is a major growth cone protein subject to regulation by GAP-43. Nature 344, 836-841. doi: 10.1038/344836a0

Sudo, H., Hashimoto, Y., Niikura, T., Shao, Z., Yasukawa, T., Ito, Y., et al. (2001). Secreted Abeta does not mediate neurotoxicity by antibody-stimulated amyloid precursor protein. Biochem. Biophys. Res. Commun. 282, 548-556. doi: 10.1006/ bbrc.2001.4604

Sudo, H., Jiang, H., Yasukawa, T., Hashimoto, Y., Niikura, T., Kawasumi, M., et al. (2000). Antibody-regulated neurotoxic function of cell-surface beta-amyloid precursor protein. Mol. Cell. Neurosci. 16, 708-723. doi: 10.1006/mcne.2000. 0910

Swanson, T. L., Knittel, L. M., Coate, T. M., Farley, S. M., Snyder, M. A., and Copenhaver, P. F. (2005). The insect homologue of the amyloid precursor protein interacts with the heterotrimeric G protein Go alpha in an identified population of migratory neurons. Dev. Biol. 288, 160-178. doi: 10.1016/j.ydbio. 2005.09.029

Tabata, H., and Nagata, K. (2016). Decoding the molecular mechanisms of neuronal migration using in utero electroporation. Med. Mol. Morphol. 49, 63-75. doi: 10.1007/s00795-015-0127-y

Tachi, N., Hashimoto, Y., Nawa, M., and Matsuoka, M. (2010). TAG-1 is an inhibitor of TGFbeta2-induced neuronal death via amyloid beta precursor protein. Biochem. Biophys. Res. Commun. 394, 119-125. doi: 10.1016/j.bbrc. 2010.02.127

Torroja, L., Chu, H., Kotovsky, I., and White, K. (1999a). Neuronal overexpression of APPL, the Drosophila homologue of the amyloid precursor protein (APP), disrupts axonal transport. Curr. Biol. 9, 489-492. doi: 10.1016/S0960-9822(99) 80215-2

Torroja, L., Luo, L., and White, K. (1996). APPL, the Drosophila member of the APP-family, exhibits differential trafficking and processing in CNS neurons. J. Neurosci. 16, 4638-4650.

Torroja, L., Packard, M., Gorczyca, M., White, K., and Budnik, V. (1999b). The Drosophila beta-amyloid precursor protein homolog promotes synapse differentiation at the neuromuscular junction. J. Neurosci. 19, 7793-7803.

Trenker, R., Call, M. J., and Call, M. E. (2016). Progress and prospects for structural studies of transmembrane interactions in single-spanning receptors. Curr. Opin. Struct. Biol. 39, 115-123. doi: 10.1016/j.sbi.2016.07.001

Tucek, S., Michal, P., and Vlachova, V. (2002). Modelling the consequences of receptor-G-protein promiscuity. Trends Pharmacol. Sci. 23, 171-176. doi: 10. 1016/S0165-6147(00)01996-9

Turner, P. R., O'Connor, K., Tate, W. P., and Abraham, W. C. (2003). Roles of amyloid precursor protein and its fragments in regulating neural activity, plasticity and memory. Prog. Neurobiol. 70, 1-32. doi: 10.1016/S0301-0082(03) 00089-3
Van Nostrand, W. E., Melchor, J. P., Keane, D. M., Saporito-Irwin, S. M., Romanov, G., Davis, J., et al. (2002). Localization of a fibrillar amyloid betaprotein binding domain on its precursor. J. Biol. Chem. 277, 36392-36398. doi: 10.1074/jbc.M204676200

Walter, J., Kaether, C., Steiner, H., and Haass, C. (2001). The cell biology of Alzheimer's disease: uncovering the secrets of secretases. Curr. Opin. Neurobiol. 11, 585-590. doi: 10.1016/S0959-4388(00)00253-1

Wang, Z., Wang, B., Yang, L., Guo, Q., Aithmitti, N., Songyang, Z., et al. (2009). Presynaptic and postsynaptic interaction of the amyloid precursor protein promotes peripheral and central synaptogenesis. J. Neurosci. 29, 10788-10801. doi: 10.1523/JNEUROSCI.2132-09.2009

Watcharasit, P., Bijur, G. N., Song, L., Zhu, J., Chen, X., and Jope, R. S. (2003). Glycogen synthase kinase-3beta (GSK3beta) binds to and promotes the actions of p53. J. Biol. Chem. 278, 48872-48879. doi: 10.1074/jbc.M305870200

Wentzell, J. S., Bolkan, B. J., Carmine-Simmen, K., Swanson, T. L., Musashe, D. T., and Kretzschmar, D. (2012). Amyloid precursor proteins are protective in Drosophila models of progressive neurodegeneration. Neurobiol. Dis. 46, 78-87. doi: 10.1016/j.nbd.2011.12.047

Weyer, S. W., Klevanski, M., Delekate, A., Voikar, V., Aydin, D., Hick, M., et al. (2011). APP and APLP2 are essential at PNS and CNS synapses for transmission, spatial learning and LTP. EMBO J. 30, 2266-2280. doi: 10.1038/ emboj.2011.119

Woehler, A., and Ponimaskin, E. G. (2009). G protein-mediated signaling: same receptor, multiple effectors. Curr. Mol. Pharmacol. 2, 237-248. doi: 10.2174/ 1874-470210902030237

Wolozin, B., Iwasaki, K., Vito, P., Ganjei, J. K., Lacana, E., Sunderland, T., et al. (1996). Participation of presenilin 2 in apoptosis: enhanced basal activity conferred by an Alzheimer mutation. Science 274, 1710-1713. doi: 10.1126/ science.274.5293.1710

Xu, Y. X., Wang, H. Q., Yan, J., Sun, X. B., Guo, J. C., and Zhu, C. Q. (2009). Antibody binding to cell surface amyloid precursor protein induces neuronal injury by deregulating the phosphorylation of focal adhesion signaling related proteins. Neurosci. Lett. 465, 276-281. doi: 10.1016/j.neulet.2009.09.022

Yamatsuji, T., Matsai, T., Okamoto, T., Komatsuzaki, K., Takeda, S., Fukumoto, H., et al. (1996a). G protein-mediated neuronal DNA fragmentation induced by familial Alzheimer's disease-associated mutants of APP. Science 272, 13491352. doi: 10.1126/science.272.5266.1349

Yamatsuji, T., Okamoto, T., Takeda, S., Murayama, Y., Tanaka, N., and Nishimoto, I. (1996b). Expression of V642 APP mutant causes cellular apoptosis as Alzheimer trait-linked phenotype. EMBO J. 15, 498-509.

Yanamadala, V., Negoro, H., and Denker, B. M. (2009). Heterotrimeric G proteins and apoptosis: intersecting signaling pathways leading to context dependent phenotypes. Curr. Mol. Med. 9, 527-545. doi: 10.2174/156652409788488784

Yoshida, Y. (2012). Semaphorin signaling in vertebrate neural circuit assembly. Front. Mol. Neurosci. 5:71. doi: 10.3389/fnmol.2012.00071

Young-Pearse, T. L., Chen, A. C., Chang, R., Marquez, C., and Selkoe, D. J. (2008). Secreted APP regulates the function of full-length APP in neurite outgrowth through interaction with integrin betal. Neural Dev. 3:15. doi: 10.1186/17498104-3-15

Yu, Y., Huang, Z., Mao, Z., Zhang, Y., Jin, M., Chen, W., et al. (2016). Go is required for the release of IL-8 and TNF-alpha, but not degranulation in human mast cells. Eur. J. Pharmacol. 780, 115-121. doi: 10.1016/j.ejphar.2016.03.038

Zhou, Z. D., Chan, C. H., Ma, Q. H., Xu, X. H., Xiao, Z. C., and Tan, E. K. (2011). The roles of amyloid precursor protein (APP) in neurogenesis: Implications to pathogenesis and therapy of Alzheimer disease. Cell Adh. Migr. 5, 280-292. doi: $10.4161 /$ cam.5.4.16986

Conflict of Interest Statement: The authors declare that the research was conducted in the absence of any commercial or financial relationships that could be construed as a potential conflict of interest.

Copyright (c) 2017 Copenhaver and Kögel. This is an open-access article distributed under the terms of the Creative Commons Attribution License (CC BY). The use, distribution or reproduction in other forums is permitted, provided the original author(s) or licensor are credited and that the original publication in this journal is cited, in accordance with accepted academic practice. No use, distribution or reproduction is permitted which does not comply with these terms. 